\title{
Overview of Ligand versus Metal Centered Redox Reactions in Tetraaza Macrocyclic Complexes of Nickel with a Focus on Electron Paramagnetic Resonance Studies
}

\author{
Joshua Telser* \\ Department of Biological, Chemical and Physical Sciences, Roosevelt University, \\ 430 South Michigan Avenue, Chicago, 60605-1394 IL USA
}

Complexos de cobre(II) $\left(3 \mathrm{~d}^{9}, S=1 / 2\right)$ são estáveis e amplamente investigados por espectroscopia de ressonância paramagnética eletrônica (EPR). Já o isoeletrônico níquel(I) é muito menos comum e muito menos estudado. No entanto, níquel(I) tem interesse biológico, uma vez que o sítio ativo da metil coenzima $\mathrm{M}$ redutase $(\mathrm{MCR})$ contém um ligante macrocíclico, $\mathrm{F}_{430}$, que coordena o $\mathrm{Ni}^{\mathrm{I}}$ na sua forma ativa, $\mathrm{MCR}_{\text {red } 1}$. Assim, o comportamento redox e espectroscópico de complexos tetraazamacrocíclicos de níquel tem importância na química biomimética. O estudo desses complexos é complicado pela dificuldade na obtenção de $\mathrm{Ni}^{\mathrm{I}}$ a partir dos precursores estáveis de $\mathrm{Ni}^{\mathrm{II}}$. A redução de complexos macrocíclicos de $\mathrm{Ni}^{\mathrm{II}}$ pode gerar $\mathrm{Ni}^{\mathrm{I}}$ em certos casos, mas em muitos outros leva à redução do macrociclo, gerando um ânion radical orgânico. Estudos anteriores da formação de complexos tetraazamacrocíclicos de $\mathrm{Ni}^{\mathrm{I}}$ são aqui discutidos em termos da competição entre a redução centrada no metal e a centrada no ligante. Resultados de EPR são particularmente importantes para distinguir esses dois processos de redução, já que a formação de $\mathrm{Ni}^{\mathrm{I}}$ produz espectros de $\mathrm{EPR}$ característicos, similares aos de $\mathrm{Cu}^{\mathrm{II}}$, enquanto a redução centrada no ligante gera espectros de EPR agudos, centrados em $g=2,00$ e típicos de radicais orgânicos. Mesmo que uma redução centrada no metal ocorra, a geometria do complexo macrocíclico de $\mathrm{Ni}^{\mathrm{I}}$ resultante é amplanente variável e, consequentemente, o espectro de EPR também será. Nesse caso, a comparação é entre os extremos dos espectros típicos de complexos tetragonais distorcidos (estado fundamental $d_{x^{2}-y^{2}}$, que inclui as geometrias octaédrica tetragonalmente distorcida, piramidal de base quadrada e quadrado-planar) e dos complexos bipiramidais de base trigonal (estado fundamental $d_{z^{2}}{ }^{1}$ ). Trabalhos anteriores realizados com $\mathrm{Cu}^{\text {II }}$ foram relacionados com a situação para $\mathrm{Ni}^{\mathrm{I}}$. Os diferentes tipos de espectros de EPR desses sistemas são discutidos especificamente usando exemplos inéditos de vários complexos tatraazamacrocíclicos de níquel, incluindo $\mathrm{F}_{430}$ e a própria MCR.

Copper(II) $\left(3 \mathrm{~d}^{9}, S=1 / 2\right)$ complexes are stable and widely investigated by electron paramagnetic resonance (EPR) spectroscopy. In contrast, isoelectronic nickel(I) is much less common and much less investigated. Nickel(I), however, is of biological interest as the active site of methyl coenzyme $\mathrm{M}$ reductase (MCR) contains a tetraaza macrocyclic ligand, $\mathrm{F}_{430}$, which coordinates $\mathrm{Ni}^{\mathrm{I}}$ in its active form, $\mathrm{MCR}_{\mathrm{red}}$. As result, the redox behavior and spectroscopy of tetraaza macrocyclic complexes of nickel is of importance in biomimetic chemistry. Such efforts are complicated by the difficulty in generating $\mathrm{Ni}^{\mathrm{I}}$ from their stable, $\mathrm{Ni}^{\mathrm{II}}$, precursors. Reduction of $\mathrm{Ni}^{\mathrm{II}}$ macrocyclic complexes can afford $\mathrm{Ni}^{\mathrm{I}}$ in certain cases, but in many other cases can lead instead to reduction of the macrocycle to generate an organic radical anion. Previous studies on the formation of tetraaza macrocyclic complexes of $\mathrm{Ni}^{\mathrm{I}}$ are discussed in terms of the competition between metal-centered and ligandcentered reduction. EPR results are particularly important in making the distinction between these two reduction processes, as formation of $\mathrm{Ni}^{\mathrm{I}}$ gives characteristic EPR spectra similar to those for $\mathrm{Cu}^{\mathrm{II}}$, while ligand-centered reduction gives narrow EPR spectra at $g=2.00$, typical of organic radicals. Even if metal-centered reduction occurs, the geometry of the resulting $\mathrm{Ni}^{\mathrm{I}}$ macrocyclic complex is highly variable and, as a result, the EPR spectral appearance is highly variable. In this case, the comparison is between the extremes of spectra typical for tetragonally distorted complexes $\left(d_{x^{2}-y^{2}}{ }^{1}\right.$ ground state, which includes tetragonally distorted octahedral, square pyramidal and square planar geometries) and those for trigonal bipyramidal complexes ( $d_{z^{2}}{ }^{1}$ ground state). Previous work on $\mathrm{Cu}^{\text {II }}$ was related to the situation for $\mathrm{Ni}^{\mathrm{I}}$. The different types of EPR spectra for such systems are specifically discussed using previously unpublished examples of several tetraaza macrocyclic complexes of nickel, including $\mathrm{F}_{430}$ and MCR itself.

Keywords: nickel, coordination chemistry, bioinorganic chemistry, EPR, redox chemistry

*e-mail: jtelser@ roosevelt.edu 


\section{Introduction}

\subsection{General background on electron paramagnetic resonance (EPR) spectroscopy}

Electron paramagnetic resonance (EPR) spectroscopy has been widely applied over the past six decades to the study of coordination complexes of the d block (transition metal) ions. ${ }^{1,2}$ Among the many possible $\mathrm{d}^{n}$ electronic configurations found, the $\mathrm{d}^{9}$ configuration has been particularly well studied. ${ }^{1-6}$ This is the case for several reasons, chemical and physical. In the chemical context, the $\mathrm{d}^{9}$ configuration is best represented by $\mathrm{Cu}^{\mathrm{II}}$, which forms a vast number of stable coordination complexes, ${ }^{7}$ many of which have biological relevance. ${ }^{3,8-10}$ In the physical context, the $\mathrm{d}^{9}(S=1 / 2)$ configuration is very amenable to study by EPR spectroscopy since there are no complications from intermolecular electronelectron interactions in mononuclear complexes. As long as the $\mathrm{Cu}^{\mathrm{II}}$ sites are sufficiently diluted, there are no intramolecular electron-electron interactions either, although these can be observed in undiluted solids. ${ }^{11}$ It should also be noted that EPR spectra of multi-Cu ${ }^{\text {II }}$ centers can be intricate due to intramolecular exchange coupling. ${ }^{12}$ Equally important, the EPR spectra of $\mathrm{d}^{9}$ systems are highly informative in terms of providing information on molecular geometry and chemical bonding. This utility was demonstrated many years ago for $\mathrm{Cu}^{\mathrm{II}}$ coordination complexes by Maki and McGarvey, ${ }^{13,14}$ and a more qualitative analysis of $\mathrm{Cu}^{\mathrm{II}}$ EPR spectra has been very useful in bioinorganic chemistry. ${ }^{3}$ In contrast, mononuclear complexes with multiple electron/holes, however, such as those with the $\mathrm{d}^{8}$ electronic configuration $\left(\mathrm{Ni}^{\mathrm{II}}\right.$ in many coordination environments, such as tetrahedral and octahedral), often exhibit complicated intramolecular electron-electron interactions that arise from spin-orbit and spin-spin coupling. ${ }^{1,15}$ These effects can lead to significant zerofield splitting (zfs) and hence difficulty in obtaining EPR spectra at conventional microwave frequencies (i.e., X-band: ca. $9 \mathrm{GHz}$ ). Use of high frequencies (> $95 \mathrm{GHz})$ combined with high magnetic fields (up to $25 \mathrm{~T}$ ), however, can yield EPR spectra of such "EPR-silent" $\mathrm{Ni}^{\mathrm{II}}$ complexes, both four-coordinate ${ }^{16}$ and six-coordinate. ${ }^{17}$

\subsection{Background on nickel(I) and on methyl CoM reductase (MCR)}

Other than $\mathrm{Cu}^{\mathrm{II}}$, what transition metal ions have the $\mathrm{d}^{9}$ electronic configuration? Silver(II) is uncommon, but can be found and Brown and Hoffman have shown that the EPR spectra of a $\mathrm{Ag}^{\text {II }}$ porphyrin can be analyzed analogously to the corresponding $\mathrm{Cu}^{\mathrm{II}}$ complex. ${ }^{18}$ Other possibilities lie outside of Group 11. These could include Group 9 complexes in the zero oxidation state, e.g., $\mathrm{Co}^{0}$; however, such species are more realistically considered as organometallic radicals and are typically found in di- or polynuclear complexes, such as diamagnetic $\left[\mathrm{Co}_{2}(\mathrm{CO})_{8}\right]{ }^{19}$ The most viable candidate is in Group 10 , namely $\mathrm{Ni}^{\mathrm{I}}$. Relative to $\mathrm{Ni}^{\mathrm{II}}, \mathrm{Ni}^{\mathrm{I}}$ is uncommon; however, pioneering work by Busch and co-worker ${ }^{20}$ has shown the accessibility of a variety of coordination complexes of $\mathrm{Ni}^{\mathrm{I}}$. At that time, $\mathrm{Ni}^{\mathrm{I}}$ complexes were of interest only to coordination chemists; however, the discovery soon thereafter of the enzyme methyl CoM reductase (MCR) changed that situation dramatically. ${ }^{21-23} \mathrm{MCR}$ catalyzes the final step in methane generation by archaea, a process by which most of biogenic methane is created. ${ }^{22,24-26} \mathrm{MCR}$ is found in several microorganisms, of which that from Methanothermobacter marburgensis is the best characterized (the taxonomy of these organisms is complicated and has been changed over the years; older papers on MCR refer to this organism as Methanobacterium thermoautotrophicum strain Marburg). MCR contains at the active site a prosthetic group comprising a unique macrocyclic ligand, known as $\mathrm{F}_{430}$ (based on its maximum absorption wavelength), a diagram of which is shown below. ${ }^{27,28}$ In contrast to tetrapyrroles, $\mathrm{F}_{430}$ is a monoanion and is much more saturated. Each pyrroline ring has significantly different substituents and is identified by the letters A through D, so that the upper left ring in the diagram below is denoted $\mathrm{A}$, the upper right (with lactam substituent) is $\mathrm{B}$, the lower right is $\mathrm{C}$, and the lower left (with cyclohexanone substituent) is D. $\mathrm{F}_{430}$ is relatively thermally unstable and can epimerize to give the 12,13-diepimer of the propionic acid side chains on ring C; shown below with the ring designations. ${ }^{28,29}$

In the resting state, inactive enzyme, $\mathrm{F}_{430}$ contains a NiII ion, which is EPR silent at X-band, but has been studied by magnetic circular dichroism (MCD). ${ }^{30,31}$ However, the active form, $\mathrm{MCR}_{\text {red1 }}$, contains $\mathrm{Ni}^{1,},{ }^{12-35}$ as does a related form, $\mathrm{MCR}_{\mathrm{red} 2}{ }^{36} \mathrm{X}$-ray crystallography has been possible on the relatively stable, $\mathrm{Ni}^{\mathrm{II}}$ forms of $\mathrm{MCR},{ }^{37,38}$ but not on the reactive, $\mathrm{Ni}^{\mathrm{I}}$ forms. The crystal structure of the pentamethylester of $\mathrm{F}_{430}, \mathrm{~F}_{430} \mathrm{M}$, has also been reported (as the 12,13-diepimer, since this is the thermally stable form; CSD code: KOBCEJ). ${ }^{39}$

\subsection{Model complexes for MCR that are porphyrin-derived}

The discovery of MCR led to a reawakening of interest in the coordination chemistry of $\mathrm{Ni}^{\mathrm{I}}$ and specifically in model chemistry of $\mathrm{MCR}_{\mathrm{red} 1}$. Synthesis of the full structure 

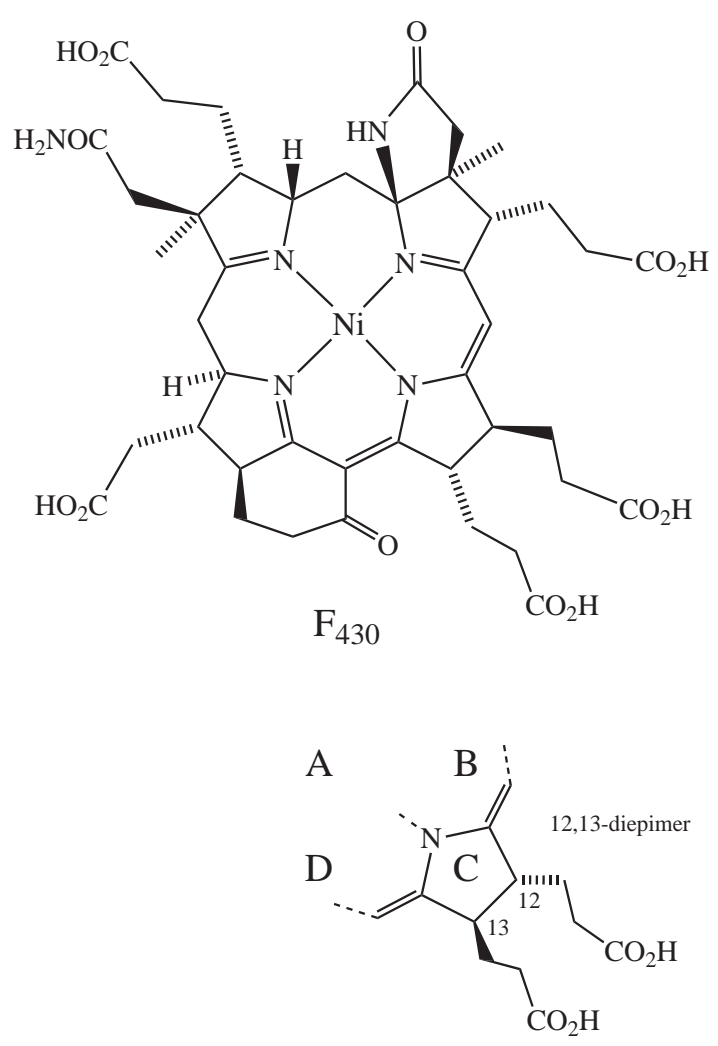

of the $\mathrm{F}_{430}$ cofactor would be a daunting task; however, the salient features of the electronic structure of the $\mathrm{Ni}^{\mathrm{I}}$ ion can be reproduced by much simpler complexes. These include some of the relatively more saturated tetraaza macrocyclic complexes first reported by Busch and coworkers ${ }^{20}$ and of the relatively less saturated, porhyrinic complexes described by Fajer and Stolzenberg and their co-workers. ${ }^{40-50}$ Among these models, the most fruitful has been that of $\mathrm{Ni}$ with the ligand octaethyisobacteriochlorin (OEiBC), a diagram of which is shown below. The octaethyl substituents aid in solubility, but may have other electronic effects. The stereochemistry at the four saturated positions (reduced cis pyrrole (pyrroline) rings A (or C) and B (or D), applying the $\mathrm{F}_{430}$ nomenclature to the diagram below) that distinguish OEiBC from its standard porphyrin analog octaethylporphyrin (OEP) is not specified. The bacteriochlorin (OEBC) has reduced trans pyrrole rings (i.e., rings $\mathrm{A} / \mathrm{B}$ and $\mathrm{C} / \mathrm{D}$ ), but has been much less studied in terms of Ni chemistry. In between the porphyrin and $\mathrm{iBC} / \mathrm{BC}$ in terms of saturation is the chlorin, in which only one pyrrole has been reduced, ${ }^{51}$ also shown below with unspecified stereochemistry.

There is also the "triply" reduced form, in which only one ring remains a pyrrole, known as octaethylpyrrocorphin (OEPC). The synthesis and crystal structure of [ $\left.\mathrm{Ni}^{\mathrm{I}}(\mathrm{OEPC})\right]$ have been reported, ${ }^{52}$ but, to our knowledge, no investigations of its reduction chemistry have been reported.

$\mathrm{Ni}(\mathrm{OEiBC})$ is prepared in the $\mathrm{Ni}^{\mathrm{II}}$ form (as are [Ni(OEP)], [Ni(OEBC)], [Ni(OEC)]), but can be reduced electrochemically, ${ }^{47}$ or by $\mathrm{Na}(\mathrm{Hg})$ amalgam in dry organic solvents to yield the $\mathrm{Ni}^{1}$ complex in solution, $[\mathrm{Ni}(\mathrm{OEiBC})]^{-} .{ }^{53}$ Other $\mathrm{Ni}^{\mathrm{I}}$ isobacteriochlorin (iBC) complexes, which contain the fused cyclohexanone ring of $\mathrm{F}_{430}$, can be analogously prepared. ${ }^{44}[\mathrm{Ni}(\mathrm{OEiBC})]^{-}$has not only spectroscopic relevance to $\mathrm{MCR}_{\text {red }}$, but also exhibits reactivity that has some similarities to that of MCR. ${ }^{42,48}$

What is striking about the effectiveness of OEiBC as a model ligand for $\mathrm{F}_{430}$ is how structurally different the two are. $F_{430}$ is a much more highly saturated and more flexible macrocycle than $\mathrm{OEiBC},{ }^{54}$ although porphyrinic macrocycles should not be thought of as the rigid disks by which they are so often depicted. Extensive studies by Ghosh and co-workers ${ }^{55,56}$ have probed the conformational flexibility and deformations on porphyrinic complexes. Even more puzzling is that among the various $\mathrm{Ni}^{\mathrm{II}}$ porphyrinic complexes, only iBCs are successfully converted into $\mathrm{Ni}^{\mathrm{i}}{ }^{44}$ The fully unsaturated, $\pi$-conjugated OEP complex of $\mathrm{Ni}^{\mathrm{II}}$ yields a ligand-centered radical upon reduction, ${ }^{47}$ although for the chlorin analog, an EPR spectrum of $\left[\mathrm{Ni}^{\mathrm{I}}(\mathrm{OEC})\right]^{-}$can be transiently observed. ${ }^{49}$ A complication with these complexes when undergoing chemical reductions is formation of phlorins, in which meso positions are reduced. Stable, square planar (sq pl),

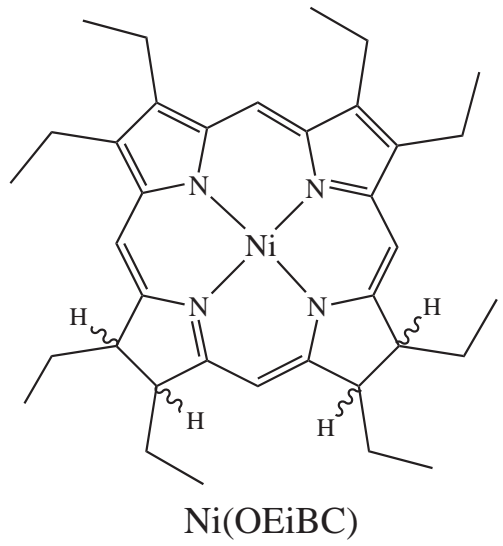

$\mathrm{Ni}(\mathrm{OE} \mathrm{BBC})$

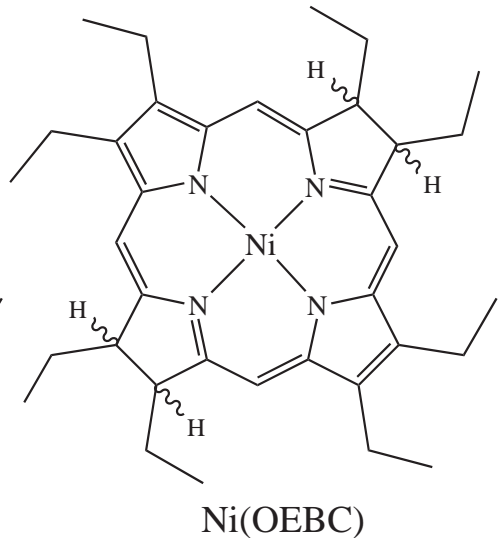

$\mathrm{Ni}(\mathrm{OEBC})$

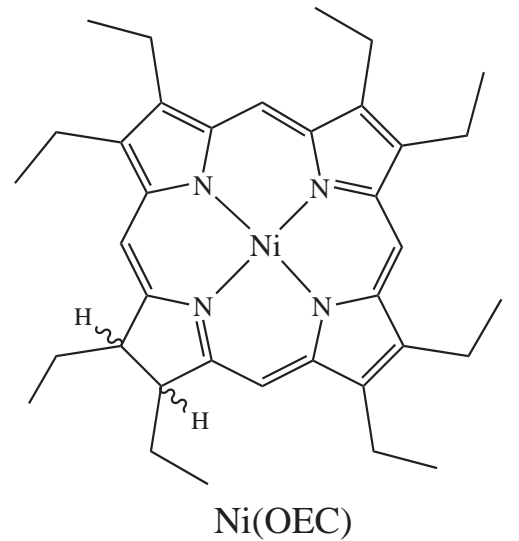


diamagnetic $\mathrm{Ni}^{\mathrm{II}}$ phlorins result eventually from reduction of both $[\mathrm{Ni}(\mathrm{OEP})]$ and $[\mathrm{Ni}(\mathrm{OEC})] \cdot{ }^{49}$ Concerning the closer models to $\mathrm{F}_{430}$, namely those with the fused cyclohexanone ring, in both their porphyrin and chlorin forms (shown below), reduction gives stable complexes well characterized in solution by EPR, optical, and X-ray spectroscopic techniques. For both of these complexes, the EPR spectra exhibit a very slight $g$ anisotropy indicating a small contribution from spin density on Ni $3 \mathrm{~d}$ orbitals, however these species can by no means be considered as authentic $\mathrm{Ni}^{\mathrm{I}}{ }^{44}$

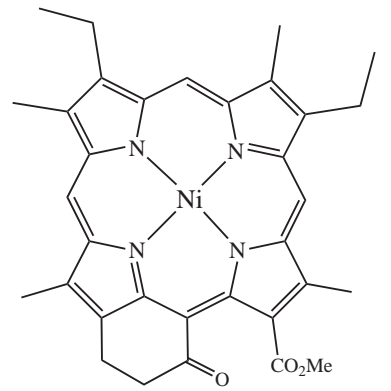

$\mathrm{F}_{430}$ model porphyrin

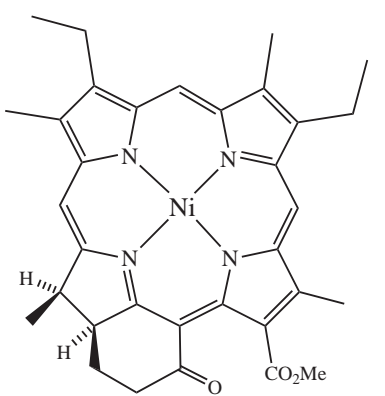

$\mathrm{F}_{430}$ model chlorin
The ligand-centered reduction might be expected for the porphyrins (OEP and the $\mathrm{F}_{430}$ model), since they are as different from $\mathrm{F}_{430}$ as is possible in terms of $\pi$-conjugation and thus have the greatest availability of ligand-centered orbitals of suitable (low) energy to be electron acceptors. The fused cyclohexanone ring, while leading to a closer model for authentic $\mathrm{F}_{430}$, appears to have no effect at preventing ligand-centered reduction. Renner et al. ${ }^{44}$ also prepared hexahydro- and octahydroporphyrins (structural diagrams shown below; note that there are two regioisomers of the hexahydroporphyrin (CSD code: KODHAM), depending on which one of the two meso alkenes is reduced; both are reduced in the octahydroporphyrin shown on the right; the hydrogens added to the meso positions are not shown). These tetraaza macrocycles are less $\pi$-conjugated than the iBCs and reproduce the structure of $\mathrm{F}_{430}$ as closely as one could reasonably hope for, yet they yield even more purely ligand centered ( $\pi$-anion) radicals upon reduction, as shown by EPR spectra that consist of a narrow signal at

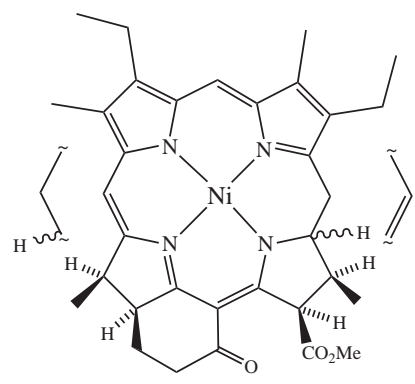

$\mathrm{F}_{430}$ model hexahydroporphyrin

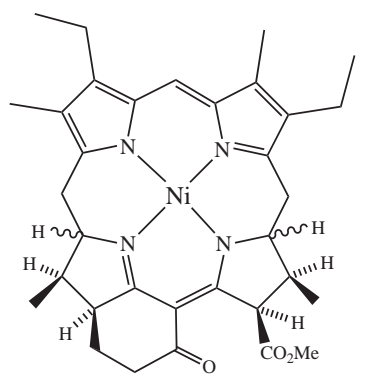

$\mathrm{F}_{430}$ model octahydroporphyrin $g=2.0029$ (essentially the free electron value, $g_{e}=2.0023$, so that there are no d orbital contributions to the SOMO whatsoever). ${ }^{44}$

Although EPR spectroscopy is a convincing indicator of metal versus ligand-centered reduction, Renner et al. ${ }^{44}$ also employed X-ray absorption spectroscopic methods (XAS, EXAFS) that independently show the reduction of $\mathrm{Ni}^{\mathrm{II}}$ to $\mathrm{Ni}^{\mathrm{I}}$ and the associated changes in $\mathrm{Ni}-\mathrm{N}$ bond lengths. The larger $\mathrm{Ni}^{\mathrm{I}}$ ion can be accommodated by a distortion in which two Ni-N bonds lengthen significantly, while the other two shorten slightly relative to the $\mathrm{Ni}^{\mathrm{II}}$ parent complex. Thus the ability of the specific macrocycle to adjust to the size changes in the nickel ion contributes what is in a sense a steric effect in determining the site of reduction. ${ }^{47}$

\subsection{Model complexes for MCR that are saturated macrocycle-derived}

If one then begins from the other direction, namely the totally saturated macrocycle 1,4,8,11-tetraazacyclotetradecane ([14]ane $\mathrm{N}_{4}$, cyclam), and its variously methyl substituted analogs (specifically, $\mathrm{Me}_{6}[14] \mathrm{aneN} \mathrm{N}_{4}$, shown below), then $\mathrm{Ni}^{\mathrm{I}}$ complexes result upon electrochemical reduction of the $\mathrm{Ni}^{\mathrm{II}}$ parent complex. ${ }^{20}$ This result is perhaps the only one that is readily expected since there are no ligand-based $\pi$ MOs to act as electron acceptors. However, introduction of only minimal $\pi$-bonding into the macrocyclic ligand can lead to generation of ligandcentered, as opposed to metal-centered (i.e., $\mathrm{Ni}^{\mathrm{I}}$ ) reduction products. The results are summarized in the scheme below, where "Ni" indicates metal-centered reduction (upper row of diagram) and " "- " indicates ligand-centered reduction (lower row). Lovecchio, Gore and Busch studied a number of other such complexes, however the scheme below depicts the salient macrocyclic ligand types. ${ }^{20}$ Related studies were subsequently performed by Gagné and coworkers ${ }^{57}$ on these and analogous complexes with borate linked bisdimine ligands (not shown). A number of these complexes were later studied by EXAFS by Furenlid $e t$ al..$^{58}$

In this wide range of macrocyclic complexes, as long as the imino groups are fully $\pi$-isolated, then the reduction is metal centered; all that is necessary for ligand-centered reduction is to have a single conjugated $\alpha$-diimine functionality. ${ }^{57}$ Complexes of $\mathrm{Ni}^{\mathrm{II}}$ with acyclic, as opposed to macrocyclic, $\alpha$-diimine ligands $\left(\left[\left(\mathrm{R}^{\prime} \mathrm{N}=\mathrm{C}(\mathrm{R}) \mathrm{C}(\mathrm{R})=\mathrm{NR}^{\prime}\right) \mathrm{MX}_{2}\right]\right.$; $\mathrm{M}=\mathrm{Ni}^{\mathrm{II}}, \mathrm{Pd}^{\mathrm{II}} ; \mathrm{X}=$ halide, alkyl etc) are of great interest in their own right, due to their activity as alkene polymerization catalysts. ${ }^{59,60}$ It should also be noted that the related, $\beta$-diketiminate ligand $\left(\mathrm{NacNac},\left(\mathrm{RC}\left(=\mathrm{NR}^{\prime}\right) \mathrm{CH}\left(=\mathrm{NR}^{\prime}\right) \mathrm{CR}\right)^{-}\right)$ has been widely used for a wide variety of $\mathrm{d}$ and $\mathrm{p}$ block metal ions, and many of these complexes have catalytic 

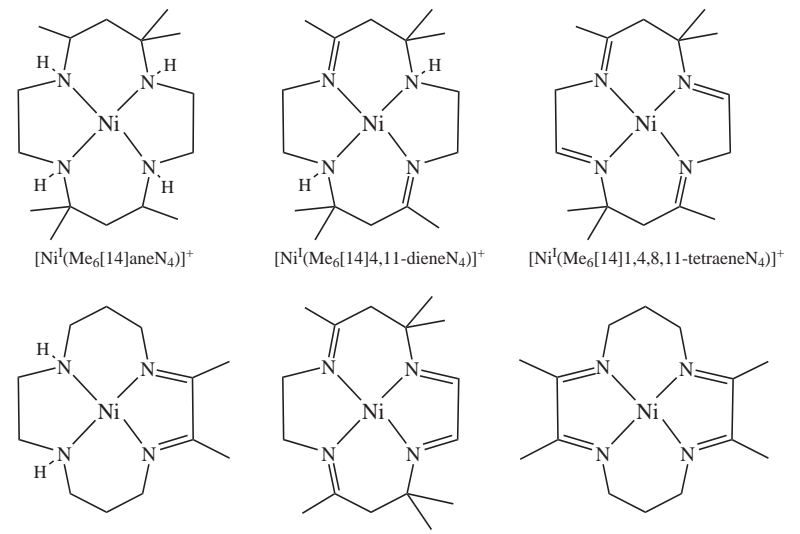

$\left[\mathrm{Ni}^{\mathrm{II}}\left(\mathrm{Me}_{2}[14] 1,3-\text { dieneN }_{4}\right)^{-{ }^{-}}\right]^{+}\left[\mathrm{Ni}^{\mathrm{II}}\left(\mathrm{Me}_{6}[14] 1,3,7,11-\text { tetraeneN }{ }_{4}\right)^{-{ }^{-}}\right]^{+}\left[\mathrm{Ni}^{\mathrm{II}}\left(\mathrm{Me}_{4}[14] 1,3,8,10 \text {-tetraeneN }{ }_{4}\right)^{-}\right]^{+}$

activity as well. ${ }^{60,61}$ Bai et al. ${ }^{62}$ provide an example of such a $\mathrm{Ni}^{\mathrm{II}}$ complex, and also provide a comprehensive listing of references on $\beta$-diketiminato complexes. These workers have also isolated $\mathrm{Ni}^{1} \beta$-diketiminato complexes, ${ }^{63}$ which indicates that the $\beta$-diketiminate ligand is not reduced, despite its extensive $\pi$-conjugation. A point that to my knowledge has not been made before is that $\mathrm{F}_{430}$ itself can be thought to contain a $\beta$-diketiminate group, as shown below in red, which is not the case for any of the [14]1,4,8,11-dior tetraene complexes shown above.
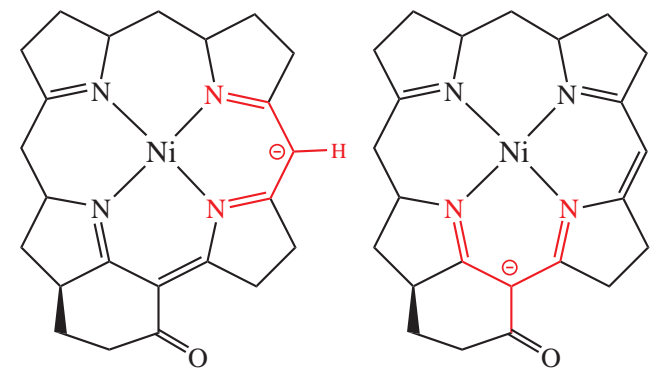

\subsection{Computational studies on tetraazamacrocyclic Ni complexes}

There are no obvious "rules of thumb" for a simple coordination chemist to use as guidelines as to whether a given $\mathrm{Ni}^{\mathrm{II}}$ complex with amino/imino ligands will be reduced to a $\mathrm{Ni}^{\mathrm{I}}$ complex, or to an organic radical anion species. Only the extrema in terms of macrocyclic ligand $\pi$-conjugation can be easily defined in that no $\pi$-conjugation (e.g., fully saturated [14] $\mathrm{aneN}_{4}$ ) gives $\mathrm{Ni}^{\mathrm{I}}$, and maximum $\pi$-conjugation (e.g., fully unsaturated (aromatic) OEP) gives a ligandcentered radical. This problem thus represents a potentially fruitful area for application of computational methods, and indeed such studies have already been performed on $\mathrm{MCR} / \mathrm{F}_{430}$ and related macrocyclic model systems. ${ }^{64-69}$

Of particular relevance is the very recent study by Ryeng, Gonzalez and Ghosh. ${ }^{69}$ These workers performed an extensive DFT study of a carefully selected series of
Ni hydroporphyrin complexes. These included chlorin, $\mathrm{iBC}$, and $\mathrm{BC}$ ligands with no substituents, and each with tetramethyl and octaethyl substituents. Complexes with heteroatom substitution, i.e., oxa- and thiaporphyrins, which have been studied experimentally, ${ }^{70}$ were also investigated computationally; however, these are not relevant to the present discussion which is limited to tetraaza complexes of Ni. As is characteristic of the Ghosh group, the results are very comprehensive. We point out here only that relative to the $\mathrm{Ni}^{\mathrm{II}}$ parent complex, $\left[\mathrm{Ni}^{\mathrm{I}}(\mathrm{OEC})\right]^{-}$and $\left[\mathrm{Ni}^{\mathrm{I}}(\mathrm{OEBC})\right]^{-}$ are actually calculated to be at lower energy than their ligand-reduced forms (by 0.2-0.3 eV). Apparently, these forms are not sufficiently stabilized in solution to persist indefinitely, suffering from other reaction pathways, such as phlorin formation. The calculation for $\left[\mathrm{Ni}^{\mathrm{I}}(\mathrm{OEiBC})\right]^{-}$, however, indicates that this form is much lower in energy (by $0.55 \mathrm{eV}$ ) than the ligand-reduced form, $\left[\mathrm{Ni}^{\mathrm{II}}\left(\mathrm{OEiBC} \mathrm{C}^{\circ}\right)\right]^{-}$, which apparently leads to its stability in solution. This stability has allowed the full EPR/ENDOR spectroscopic characterization of $\left[\mathrm{Ni}^{\mathrm{I}}(\mathrm{OEiBC})\right]^{-50}$. This energetic result is more the consequence of relative instability of the ligand radical anion than of relative stability of the $\mathrm{Ni}^{\mathrm{I}}$ form. Conformational flexibility in the OEiBC macrocycle relative to the more rigid OEC and OEBC (and presumably OEP) is the crucial factor in stabilizing the $\mathrm{Ni}^{\mathrm{I}}$ form. This quantitative result from computations agrees with earlier, qualitative proposals. ${ }^{49,51}$

Wondimagegn and Ghosh $^{68}$ had earlier studied $\mathrm{F}_{430}$ itself and shown that this unique ligand has unique conformational characteristics that help support the $\mathrm{Ni}^{\mathrm{I}}$ species observed by a variety of spectroscopic methods. ${ }^{40,41,50}$ Nevertheless, the situation with more reduced, and presumably more flexible, macrocyclic complexes, such as those studied by the groups of Busch, ${ }^{20}$ and Gagné, ${ }^{57}$ has yet to be resolved.

\section{EPR Results for Tetraazamacrocyclic Ni Complexes}

\subsection{Overview of case studies of individual Ni complexes}

We describe here EPR studies on several macrocyclic complexes of nickel that span a variety of tetraaza macrocycle coordination. Also included are EPR spectra of the isolated MCR cofactor, $\mathrm{F}_{430}$, in its reduced, $\mathrm{Ni}^{\mathrm{I}}$ form $\left(\mathrm{Ni}^{\mathrm{l}} \mathrm{F}_{430}\right)$, together with the holoenzyme form that contains this species, $\mathrm{MCR}_{\mathrm{redl}}$. In the case of enzymes, introduction of magnetically active nuclei is often much more feasible than in model complexes. The anaerobic organisms that are the source of MCR can be grown on medium enriched in, e.g. ${ }^{61} \mathrm{Ni}(I=3 / 2,1.13 \%$ natural abundance $)$, whereas chemical synthesis using such isotopes is very expensive. 
Such isotopologs definitively showed the role of nickel in MCR. ${ }^{22,32,35}$

Concerning the tetraaza macrocyclic model complexes for MCR, we first present the EPR spectra of $t c t-\left[\mathrm{Ni}^{\mathrm{I}}(\mathrm{OEiBC})\right]^{-}$, which represents the most unsaturated macrocycle to give a stable $\mathrm{Ni}^{\mathrm{I}}$ species in solution; the $t t t$ - and $t c t$ - isomers (see diagram below) gave identical EPR results. No solid $\mathrm{Ni}^{1}$ OEiBC complex has been isolated. Surprisingly, to our knowledge, no crystal structure of $\left[\mathrm{Ni}^{\mathrm{II}}(\mathrm{OEiBC})\right]$ has been reported (nor of [Ni(OEC)]), although structures of $\left[\mathrm{Ni}^{\mathrm{II}}(\mathrm{OEBC})\right]$ (CSD code: DEGTAK ${ }^{52}$ ) and $\left[\mathrm{Ni}^{\mathrm{II}}(\mathrm{OEP})\right]$ (several structures, of which the most recent has CSD code: NOEPOR02 ${ }^{71}$ ), and $[\mathrm{Ni}(\mathrm{OEPC})]$ (CSD code: DEGSUD $\left.{ }^{52}\right)$ are known. However, the crystal structures of the $\mathrm{Pd}^{\mathrm{II}}$ series [Pd(OEP)], $[\mathrm{Pd}(\mathrm{OEC})]$, and $t c t-[\mathrm{Pd}(\mathrm{OEiBC})]$ have been reported by Stolzenberg et al..$^{72}$ The larger size of $\mathrm{Pd}^{\mathrm{II}}$ allowed a better probe of the effect of ring reduction than for the $\mathrm{Ni}^{\mathrm{II}}$ analogs. Lastly, the crystal structures of the series [Ni(TMP)], $[\mathrm{Ni}(\mathrm{TMC})]$ and $[\mathrm{Ni}(\mathrm{TMiBC})]($ where $\mathrm{TMiBC}=$ dianion of 5,10,15,20-tetramethylisobacteriochlorin, and analogously for TMP and TMC) have been reported; $; 3,74$ however, these tetrapyrroles have substituents unlike those of $\mathrm{F}_{430}$ (i.e., at the meso positions, rather than at the $\beta$ positions (pyrroles/ pyrrolines)) and are considered here only in passing. The relative stability of $\left[\mathrm{Ni}^{\mathrm{I}}(\mathrm{TMC}, \mathrm{TMBC}, \mathrm{TMiBC})\right]^{-}$ versus $\left[\mathrm{Ni}^{\mathrm{II}}\left(\mathrm{TMC}, \mathrm{TMBC}, \mathrm{TMiBC}^{\circ}\right)\right]^{-}$has been studied computationally by Ryeng et al. ${ }^{69}$ who showed that ligand-centered reduction is energetically favored for the TMC and TMBC complexes, but is less favored (by $c a$. $0.55 \mathrm{eV}$; similar to the result for $\mathrm{OEiBC}$ ) for the TMiBC complex. Despite this, we are not aware of any report of a $\mathrm{Ni}^{\mathrm{I}}$ species upon reduction of $\mathrm{Ni}(\mathrm{TMiBC})$. Perhaps the recent work of Ryeng et al. ${ }^{69}$ will inspire a reinvestigation of this process in the meso-substituted $\mathrm{Ni}^{\mathrm{II}}$ tetrapyrrole series.

Moving in the direction of greater saturation, we also describe studies on a nickel complex of a diene derivative of 1,4,8,11-tetraazacyclotetradecane, $\mathrm{Me}_{6}[14] 4,11$ diene $\mathrm{N}_{4}$ (formally 5,7,7,12,14,14-hexamethyl-1,4,8,11tetraazacyclotetradeca-4,11-diene), in which there is no conjugation of the two imines, so that a $\mathrm{Ni}^{\mathrm{I}}$ species is formed upon reduction. ${ }^{20,57,58}$ Two geometrical forms of this complex are found, rac and meso, as shown in the diagram below, and each has been structurally characterized in the $\mathrm{Ni}^{\mathrm{II}}$ state (CSD codes: KUGNEF (meso), MAZTNI02 $(\mathrm{rac})) .{ }^{75}$ The structure of only the meso form has been determined for $\mathrm{Ni}^{\mathrm{I}}$ (as $\left[\mathrm{Ni}\left(\mathrm{Me}_{6}[14] 4,11-\right.\right.$ dieneN $\left.\left._{4}\right)\right]\left(\mathrm{ClO}_{4}\right)$, CSD code: KINNOK). ${ }^{58}$ The specific $\mathrm{Ni}^{\mathrm{I}}$ solid state sample studied here was a mixture of these rac and meso forms; this heterogeneity is maintained in solution.
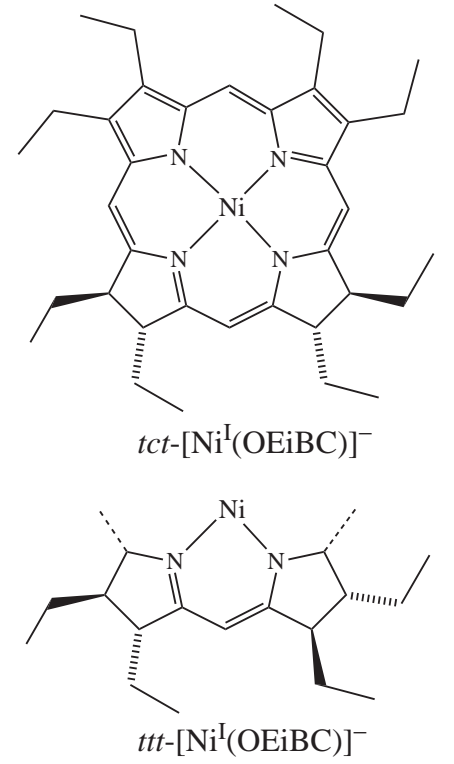

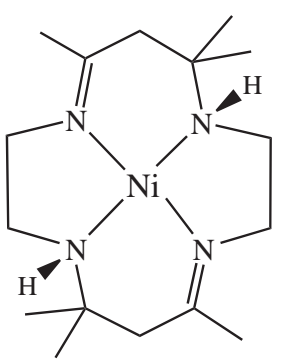

racemic

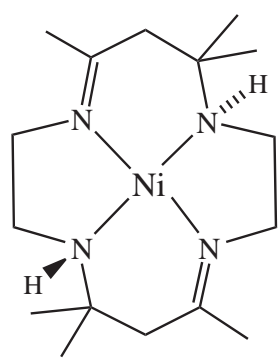

meso
$\left[\mathrm{Ni}^{\mathrm{I}}\left(\mathrm{Me}_{6}[14] 4,11-\text { diene } \mathrm{N}_{4}\right)\right]^{+}$

The final isolable tetraaza macrocyclic complex to be described is that of the fully saturated ligand 1,4,8,11-tetramethyl-1,4,8,11-tetraazacyclotetradecane (tetramethylcyclam, tmc, [14]ane $(\mathrm{NMe})_{4}$ ) ${ }^{76}$ for which two stereoisomers are available as in the diagrams shown below. Crystal structures of a variety of $\left[\mathrm{Ni}^{\mathrm{II}}(\mathrm{tmc})\right]^{2+}$ complexes, several with axial ligands, but none with nitrile(s), have been reported; that most relevant to this study is $R R S S-\left[\mathrm{Ni}^{\mathrm{II}}(\mathrm{tmc})\right]\left(\mathrm{CF}_{3} \mathrm{SO}_{3}\right)_{2}$ (CSD code: DONCAK), ${ }^{77}$ which is a rigorously sq pl complex. It must be noted that although isomerically pure $\left[\mathrm{Ni}^{\mathrm{II}}(\mathrm{tmc})\right]^{2+}$ complexes can be isolated, this isomeric integrity is not maintained upon reduction. Chemical reduction of either $\mathrm{Ni}^{\mathrm{II}}$ pure isomer yields solutions containing both the RSRS- and $R R S S-\left[\mathrm{Ni}^{\mathrm{I}}(\mathrm{tmc})\right]^{+}$isomers. ${ }^{76,78}$ For solubility reasons, the $R R S S$ isomer crystallized selectively, as $R R S S-\left[\mathrm{Ni}^{\mathrm{I}}(\mathrm{tmc})\right]$ $\left(\mathrm{CF}_{3} \mathrm{SO}_{3}\right) \cdot \mathrm{NaCF}_{3} \mathrm{SO}_{3}$ (CSD code: ZIMWUN), ${ }^{76}$ however the solutions studied here contain both isomers, albeit in unknown proportion. At equilibrium in aqueous solution, the RRSS/RSRS ratio is roughly $3: 1 .^{78}$

Related studies by Meyerstein and co-workers ${ }^{79,80}$ on a variant of tmc with macrocycle methylation (officially, 

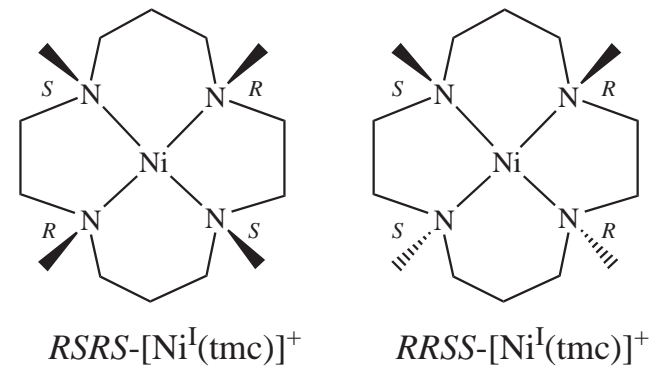

$1 R S, 4 R S, 7 R S, 8 S R, 11 S R, 14 S R)-1,4,5,5,7,8,11,12,12,14-$ decamethyl-1,4,8,11-tetraazacyclotetradecane; referred to herein as $C$-meso-[ $\left.\mathrm{Me}_{6}[14] \mathrm{ane}(\mathrm{NMe})_{4}\right]$, or as $\mathrm{Me}_{6} \mathrm{tmc}$; diagram shown below) also showed the stability of $\mathrm{Ni}^{\mathrm{I}}$. The structure of only the $\mathrm{Ni}^{1 I}$ form of this complex has been reported (as $\left[\mathrm{Ni}^{\mathrm{II}}\left(\mathrm{Me}_{6} \mathrm{tmc}\right)\right]\left(\mathrm{ClO}_{4}\right)_{2}$; CSD code: DUKPUU). ${ }^{81}$

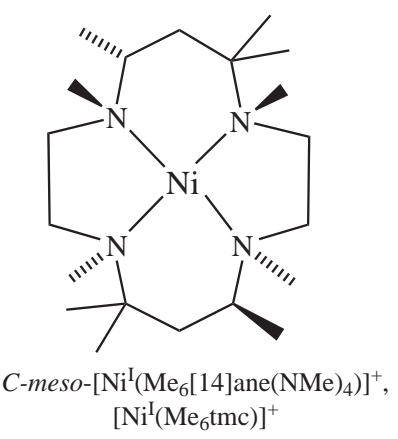

Lastly, we describe the EPR spectra of the unstable species formed upon $\gamma$-irradiation of both $\left[\mathrm{Ni}^{\mathrm{I}}(\mathrm{OEiBC})\right]$ and $\left[\mathrm{Ni}^{\mathrm{II}}(\mathrm{OEP})\right]$ at $77 \mathrm{~K}$. This cryoreduction technique, in which $\gamma$-irradiation ejects electrons from the appropriate solvent (various organic solvents, such as ethanol, or water/ glycerol) has been pioneered by Davydov and applied to a wide variety of metalloproteins, including diiron-oxo proteins, ${ }^{82}$ iron-sulfur proteins, ${ }^{83}$ heme proteins,${ }^{84,85}$ and MCR itself. ${ }^{86}$ These new results show that it is possible to generate a $\mathrm{Ni}^{\mathrm{I}}$ porphyrin, but that it can survive only at cryogenic temperatures. This work is analogous, but in striking contrast, to the studies using UV-irradiation in fluid solution, followed by freezing in liquid nitrogen, which showed only the generation of an anion radical, $\left[\mathrm{Ni}^{\mathrm{II}}\left(\mathrm{OEP}^{-}\right)\right] .^{49} \mathrm{In}$ a related technique, radiolysis (pulsed or steady-state), using electrons generated by a linear accelerator, has also been used to generate $\mathrm{Ni}^{\mathrm{I}}$ from tetraaza macrocyclic $\mathrm{Ni}^{\mathrm{il}}$ complexes. ${ }^{79,80}$

\subsection{Sources of complexes described in case studies and experimental protocol}

The complexes studied were obtained from a variety of sources. Samples of Methanothermobacter marburgensis
$\mathrm{MCR}_{\text {red1 }}$ were provided by Prof. Stephen W. Ragsdale (University of Michigan, Ann Arbor, MI, USA) and prepared by reduction with $\mathrm{Ti}^{\mathrm{III}}$ citrate as described previously. ${ }^{87}$ Isolated native $\mathrm{F}_{430}$ and its 12,13-diepimer were provided by Prof. Robert A. Scott (University of Georgia, Athens, GA, USA) and converted in his laboratory to their $\mathrm{Ni}^{\mathrm{I}}$ forms by reduction with $\mathrm{Ti}^{\mathrm{III}}$ citrate as described previously. ${ }^{50}$ RRSS-[Ni' $\left.\left(\mathrm{tmc}^{\mathrm{m}}\right)\right]\left(\mathrm{CF}_{3} \mathrm{SO}_{3}\right) \cdot \mathrm{NaCF}_{3} \mathrm{SO}_{3}$ was provided by Prof. Charles G. Riordan (University of Delaware, Newark, DE, USA) and prepared in his laboratory following literature procedures. ${ }^{76}\left[\mathrm{Ni}^{\mathrm{I}}\left(\mathrm{Me}_{6}[14] 4,11-\right.\right.$ dieneN $\left.\left._{4}\right)\right]\left(\mathrm{ClO}_{4}\right)$ (mixture of rac and meso forms) was provided by Dr. Etsuko Fujita, Brookhaven National Laboratory, Upton, NY, USA and prepared in her laboratory following literature procedures. ${ }^{57,58} \mathrm{The}^{\mathrm{Ni}}{ }^{\mathrm{I}}$ forms of these complexes were provided as solids and then dissolved under nitrogen atmosphere in dry $n$-butyronitrile $/ n$-propionitrile $(9: 7 \mathrm{v} / \mathrm{v})$, which mixture forms a good glass for EPR spectroscopy. The complexes $t t t$ - and $t c t-\mathrm{Ni}(\mathrm{OEiBC})$ were prepared and chromatographically separated by Dr. Mark W. Renner (Brookhaven National Laboratory) as described previously. ${ }^{50}$ The $\mathrm{Ni}^{1}$ forms of these complexes were generated in Dr. Renner's laboratory by reduction using $\mathrm{Na}(\mathrm{Hg})$ amalgam in dry 2-methyltetrahydrofuran (2-Methf) solution, ${ }^{50}$ and shipped at low temperature for EPR measurements at Northwestern University. The complex $\left[\mathrm{Ni}^{\mathrm{II}}(\mathrm{OEP})\right]$ was obtained from Porphyrin Products (now Frontier Scientific, Logan, UT, USA).

EPR spectra at 9.0-9.7 $\mathrm{GHz}$ (X-band) of $\mathrm{MCR}_{\text {red1 }}$ samples were recorded by Dr. Yih-Chern Horng at the University of Nebraska, Lincoln, NE, USA on a Bruker ESP $300 \mathrm{E}$ spectrometer. EPR spectra at $34-36 \mathrm{GHz}$ ( $\mathrm{K}_{\mathrm{a}}$-band, often, but erroneously, referred to as Q-band) were recorded on a modified Varian spectrometer at Northwestern University, Evanston, IL, USA. Experimental conditions are given in the figure captions. The $35 \mathrm{GHz}$ spectra were recorded under "passage" conditions, ${ }^{88}$ so that the signal appears as an absorption, rather than first derivative lineshape. The figures generally present digital derivatives in addition to or instead of the original, passage spectrum so that the appearance is consistent with typical EPR spectra, such as those reported elsewhere for such $\mathrm{Ni}^{\mathrm{I}}$ species.

$\mathrm{Ni}^{\mathrm{II}}(\mathrm{OEP})$ and $\mathrm{Ni}^{\mathrm{II}}(\mathrm{OEiBC})$ samples in 2-Methf solution were $\gamma$-irradiated at $77 \mathrm{~K}$. The irradiation was done by Dr. Roman Davydov, Northwestern University, using a Gammacell $200{ }^{60} \mathrm{Co}$ irradiator at the University of Chicago Pritzker School of Medicine, using procedures developed by him. ${ }^{82,84,89-91}$ The irradiated samples were maintained at $77 \mathrm{~K}$ (or lower) throughout the subsequent EPR spectroscopic measurements. 
All computer programs for EPR simulation (QPOWA, written originally by Belford and co-workers at the U. of Illinois, Urbana, IL, USA, ${ }^{92,93}$ and DDPOWH) and ligand field analysis (DSOXF, DDN package) are written in FORTRAN (g77) and are available from the author.

\section{3. $35 \mathrm{GHz}$ EPR Spectra of $\mathrm{Ni}^{\mathrm{l}} \mathrm{F}_{430}$ and $\left[\mathrm{Ni}^{\mathrm{l}}(\mathrm{OEiBC})\right]^{-}$}

Among the various tetraaza macrocyclic complexes of $\mathrm{Ni}^{\mathrm{I}}$ studied here, the simplest EPR spectrum is that for the most structurally elaborate macrocycle, namely $\mathrm{F}_{430}$. Figure 1 presents $35 \mathrm{GHz}$ EPR spectra of $\mathrm{Ni}^{\mathrm{l}} \mathrm{F}_{430}$ and $t c t-\left[\mathrm{Ni}^{1}(\mathrm{OEiBC})\right]^{-}$. The EPR parameters for these and other $\mathrm{Ni}^{\mathrm{I}}$ species are summarized in Table 1. Use of higher microwave frequencies, here $35 \mathrm{GHz}$, often reveals rhombicity that is not resolved at X-band (ca.9 GHz). This is indeed the case for $\left[\mathrm{Ni}^{\mathrm{I}}(\mathrm{OEiBC})\right]^{-}$, by comparison of Figure 1 to the published X-band spectrum (see Figure 12 in Renner et $a l .{ }^{45}$ ), although careful EPR simulation allowed these workers to extract the two components of $g_{\perp}: \mathbf{g}=[2.061,2.083,2.2025]$, which values are essentially identical to those obtained from $35 \mathrm{GHz}$ spectra: $\mathbf{g}=[2.063,2.080,2.204] .{ }^{50} \mathrm{In}$ contrast, the $35 \mathrm{GHz}$ spectrum of $\mathrm{Ni}^{\mathrm{l}} \mathrm{F}_{430}$ is as axial in appearance as its $\mathrm{X}$-band spectrum (see Figure 3 in Holliger et al..$^{94}$ ).

It is interesting that, despite the potentially very flexible $\mathrm{F}_{430}$ macrocycle ${ }^{54,95}$ with its vast variety of sidechains, including fused lactam (B) and cyclohexanone (C) rings, and the differences among the nitrogen donors (one is not conjugated with the other three), and the presence of two different $\mathrm{Ni}-\mathrm{N}$ distances as determined by EXAFS ${ }^{40}$ the EPR spectrum of $\mathrm{Ni}^{\mathrm{l}} \mathrm{F}_{430}$ is rigorously axial (with $g_{\|}=2.244$, $\left.g_{\perp}=2.063\right)$ to within \pm 0.002 in $g$ value ( $c a .1 \mathrm{mT}$ at $35 \mathrm{GHz}, g=2.0$ ). We suggest that this may be evidence that the orientation of the in-plane components of the $\mathbf{g}$ matrix $\left(g_{x}, g_{y}\right)$ may be exactly bisecting the N-Ni-N bond angles, so that an average value results. Single crystal studies of $\mathrm{Cu}^{\mathrm{II}}$ complexes have shown that an orientation of $g_{x}, g_{y}$ non-coincident with the $\mathrm{Cu}-\mathrm{N}$ bond vector can occur. ${ }^{96,97}$ The 12,13-diepimer of $\mathrm{Ni}^{\mathrm{l}} \mathrm{F}_{430}$ was also investigated, but its $35 \mathrm{GHz}$ EPR spectrum in our hands was indistinguishable from native $\mathrm{Ni}^{\mathrm{I}} \mathrm{F}_{430}$ (not shown), although a very slight difference between the native and diepimeric forms has been reported. ${ }^{94}$ We have found that different preparations and/or slight differences in buffer/glassing agent of $\mathrm{Ni}^{\mathrm{I}} \mathrm{F}_{430}$ and of $\mathrm{MCR}_{\text {red } 1}$ give variations in $g$ values (e.g., \pm 0.005 in $g_{\|}$) that is on the order of that reported for the diepimeric versus native forms.

X-band EPR (and lower frequencies), however, can reveal hyperfine splitting that is not resolved at higher fields/frequencies. The X-band EPR spectrum reported

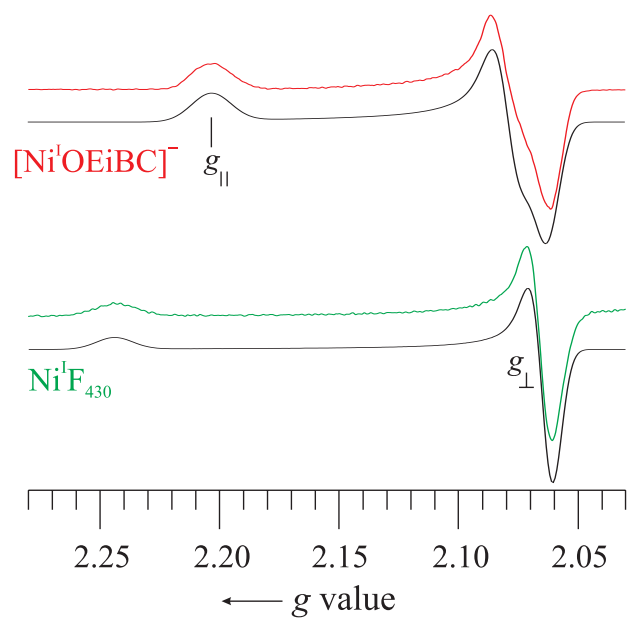

Figure 1. Experimental (dashed trace of pair (colored in online version)) and simulated (solid black trace of pair) $35 \mathrm{GHz}$ EPR spectra of $\mathrm{Ni}^{\mathrm{I}} \mathrm{F}_{430}$ in aqueous solution and of $\left[\mathrm{Ni}^{\mathrm{I} O E i B C}\right]^{-}$in 2-Methf. The spectra were recorded at $2 \mathrm{~K}$ using the dispersion mode under passage conditions; a numerical first derivative is shown. The abscissa is in $g$ value to facilitate comparison between spectra recorded at different frequencies $(35.035$ for $\left.\mathrm{Ni}^{\mathrm{I}} \mathrm{F}_{430} ; \mathrm{Nii}^{\mathrm{I} O E i B C}\right]^{-}$for $\left.35.422 \mathrm{GHz}\right)$. The simulation parameters for $\mathrm{Ni}^{\mathrm{I}} \mathrm{F}_{430}$ are $g_{\|}=2.244, g_{\perp}=2.063, W_{\|}=140 \mathrm{MHz}, W_{\perp}=90 \mathrm{MHz}$ (single crystal Gaussian linewidths, hwhm); for $\left[\mathrm{Ni}^{\mathrm{i}} \mathrm{OEiBC}\right]^{-}: g_{z}(\max )=2.204$, $g_{y}(\mathrm{mid})=2.080, g_{x}(\mathrm{~min})=2.063, W_{z}=155 \mathrm{MHz}, W_{x, y}=100 \mathrm{MHz}$.

for $\left[\mathrm{Ni}^{\mathrm{I}}(\mathrm{OEiBC})\right]^{-}$shows resolved hyperfine coupling at $g_{\perp}$ from the four, essentially equivalent, pyrrole/pyrroline nitrogens $\left(A\left({ }^{14} \mathrm{~N}\right)_{g \perp}=0.98 \mathrm{mT}, 28 \mathrm{MHz}\right),{ }^{47}$ which is not seen at $35 \mathrm{GHz}$. The EPR feature at $g_{\perp}$ for $\left[\mathrm{Ni}^{\mathrm{i}}(\mathrm{OEiBC})\right]^{-}$is qualitatively very similar to that seen for $\mathrm{Cu}^{\mathrm{II}}$ tetrapyrroles, such as $[\mathrm{Cu}(\mathrm{TPP})]^{18}$ or $[\mathrm{Cu}(\mathrm{OEP})]\left(A\left({ }^{14} \mathrm{~N}\right)_{g \perp}=42 \mathrm{MHz}\right) .{ }^{98}$ Use of even lower microwave frequencies than $\mathrm{X}$-band, such as S-band (ca. $1 \mathrm{GHz})$ or L-band $(3 \mathrm{GHz})$, might provide even better resolution of the ${ }^{14} \mathrm{~N}$ hyperfine splitting, as has been shown for $\mathrm{Cu}^{\mathrm{II}}$ complexes by Hyde and Froncisz. ${ }^{4}$ In the case of $\mathrm{Ni}^{\mathrm{I}} \mathrm{F}_{430}$, the reported X-band spectrum reveals only a hint of resolved hyperfine coupling, although "massaging" of the data (Fourier-filtered second derivative presentation) did reveal hyperfine coupling $\left(A\left({ }^{14} \mathrm{~N}\right)_{\text {iso }}=1.0 \mathrm{mT}, 29 \mathrm{MHz}\right) .{ }^{94}$ The X-band spectrum of $\mathrm{Ni}^{i} \mathrm{~F}_{430} \mathrm{M}$ (the organic-soluble, pentamethyl ester of $\mathrm{F}_{430}$ ) does show barely resolved ${ }^{14} \mathrm{~N}$ hyperfine coupling with $A\left({ }^{14} \mathrm{~N}\right)_{g \perp}=0.95 \mathrm{mT}, 27 \mathrm{MHz} .{ }^{33}$ The narrow range of ${ }^{14} \mathrm{~N}$ hyperfine coupling for these complexes indicates a commonality in bonding amongst them.

\subsection{X-band and $35 \mathrm{GHz}$ EPR Spectra of $M C R_{\text {redl }}$}

An extensive discussion of MCR, with its many forms, both EPR-active and EPR-silent, ${ }^{24-26,99-101}$ is outside the scope of this study. We present here EPR spectra only of the form that is correlated with enzyme activity, $\mathrm{MCR}_{\text {red1 }}{ }^{22,102}$ which resembles by EPR spectroscopy most closely $\mathrm{Ni}^{\mathrm{l}} \mathrm{F}_{430}$ and $\left[\mathrm{Ni}^{\mathrm{I}}(\mathrm{OEiBC})\right]^{-} .^{103} \mathrm{The} 35 \mathrm{GHz}$ spectrum 
Table 1. Frozen solution EPR parameters for EPR-active MCR forms and tetraazamacrocyclic $\mathrm{Ni}^{\mathrm{I}}$ complexes

\begin{tabular}{|c|c|c|c|}
\hline Complex, solvent & $\begin{array}{l}g \text { values } \\
\left(g_{\text {max }}, g_{\text {mid }}, g_{\text {min }}\right)\end{array}$ & $A$ values $(\mathrm{MHz})$ & Reference \\
\hline $\begin{array}{l}\mathrm{MCR}_{\text {red1 }}{ }^{a} \\
\text { aqueous buffer for all entries }\end{array}$ & $2.2745,2.0820,2.0680$ & ${ }^{14} \mathrm{~N}_{\mathrm{iso}}: 28$ & 99 \\
\hline $\mathrm{MCR}_{\mathrm{redlc}} \mathrm{b}^{\mathrm{b}}$ & $\begin{array}{l}2.2500,2.0710,2.0605 \\
2.2467,2.0671,2.0598 \\
2.2479,2.0677,2.0595\end{array}$ & $\begin{array}{l}{ }^{14} \mathrm{~N}_{\text {iso }}: 28 \\
{ }^{61} \mathrm{Ni}_{\text {max }}: 195\end{array}$ & $\begin{array}{c}99,101 \\
25\end{array}$ \\
\hline $\mathrm{MCR}_{\text {redlm }}{ }^{\mathrm{c}}$ & $2.2515,2.0730,2.0635$ & $\begin{array}{l}{ }^{14} \mathrm{~N}_{\text {iso }}: 28 \\
{ }^{61} \mathrm{Ni}_{\text {max }}: 195\end{array}$ & 99,101 \\
\hline $\mathrm{MCR}_{\mathrm{red} 1 \mathrm{a}}{ }^{\mathrm{d}}$ & $2.224,2.065,2.057$ & ${ }^{61} \mathrm{Ni}_{\max }: 200$ & This work \\
\hline $\begin{array}{l}\mathrm{MCR}_{\text {red2 }} \mathrm{e} \\
\text { aqueous buffer for both entries }\end{array}$ & $\begin{array}{l}2.2940,2.2313,2.1790 \\
2.2880,2.2348,2.1790\end{array}$ & $\begin{array}{l}{ }^{14} \mathrm{~N}_{\text {iso }}: 24.6 \\
{ }^{61} \mathrm{Ni}_{\max }: 67\end{array}$ & $\begin{array}{l}99 \\
101\end{array}$ \\
\hline $\mathrm{MCR}_{\mathrm{red} 2 \mathrm{r}}{ }^{\mathrm{e}}$ & $\begin{array}{l}2.2885,2.2339,2.1771 \\
2.2886,2.2339,2.1797\end{array}$ & & 25 \\
\hline $\begin{array}{l}\mathrm{MCR}_{\text {oxi }}^{\mathrm{f}} \\
\text { aqueous buffer }\end{array}$ & $\begin{array}{l}2.2310,2.1667,2.1532 \\
2.2312,2.1678,2.1527\end{array}$ & $\begin{array}{l}{ }^{14} \mathrm{~N}_{\text {iso }}: 27 \\
{ }^{14} \mathrm{~N}_{\text {iso }}: 27.1 \\
{ }^{61} \mathrm{Ni}_{\text {max }}: 132\end{array}$ & $\begin{array}{c}99,101 \\
24\end{array}$ \\
\hline $\begin{array}{l}\mathrm{Ni}^{\mathrm{I}} \mathrm{F}_{430} \\
\text { aqueous buffer }\end{array}$ & $\begin{array}{l}g_{\|}=2.224, g_{\perp}=2.061 \\
g_{\|}=2.244, g_{\perp}=2.063\end{array}$ & $\begin{array}{l}{ }^{14} \mathrm{~N}_{\text {iso }}: 29 \\
{ }^{14} \mathrm{~N}_{\text {iso }}: 30\end{array}$ & $\begin{array}{l}94 \\
50 \\
\end{array}$ \\
\hline $\begin{array}{l}\mathrm{Ni}^{\mathrm{I}} \mathrm{F}_{430} \mathrm{M}^{\mathrm{g}} \\
\text { thf }\end{array}$ & $2.250,2.074,2.065$ & ${ }^{14} \mathrm{~N}_{\mathrm{iso}}: 27$ & 33 \\
\hline Complex, solvent & $\begin{array}{l}g \text { values } \\
\left(g_{\max }, g_{\text {mid }}, g_{\min }\right)\end{array}$ & $A$ values $(\mathrm{MHz})$ & Reference \\
\hline $\begin{array}{l}{\left[\mathrm{Ni}^{\mathrm{I}}(\mathrm{OEiBC})\right]^{-}} \\
\text {2-Methf } \\
\text { thf }\end{array}$ & $\begin{array}{l}g_{\|}=2.201, g_{\perp}=2.073 \\
2.2025,2.083,2.061\end{array}$ & $\begin{array}{l}{ }^{14} \mathrm{~N}_{\text {iso }}: 28 \\
{ }^{14} \mathrm{~N}_{\text {iso }}: 28\end{array}$ & $\begin{array}{c}47 \\
45,50\end{array}$ \\
\hline $\begin{array}{l}\text { 2-Methf } \\
\gamma \text {-irradiation product }\end{array}$ & $\begin{array}{l}2.204,2.080,2.063 \\
g_{\perp}=2.075, g_{\|}=(2.11,2.18,2.30)\end{array}$ & ${ }^{14} \mathrm{~N}_{\text {iso }}: 30$ & This work \\
\hline $\begin{array}{l}\text { 2-Methf } \\
\gamma \text {-irradiation product, warmed }\end{array}$ & $\begin{array}{l}\text { major: } 2.195,2.105,2.095 \\
\text { minor: } g_{\perp} \approx 2.05(5), g_{\|}=2.30\end{array}$ & & This work \\
\hline $\begin{array}{l}{\left[\mathrm{Ni}^{\mathrm{I}}(\mathrm{OEC})\right]^{-}\left(\text {unstable }^{\mathrm{i}}\right.} \\
\text { thf }\end{array}$ & $2.19,2.10,1.98$ & & 49 \\
\hline $\begin{array}{l}{\left[\mathrm{Ni}^{\mathrm{I}}(\mathrm{OEP})\right]^{-}(\text {unstable })^{\mathrm{j}}} \\
\gamma \text {-irradiation product } \\
\text { 2-Methf }\end{array}$ & $2.179,2.093,2.090$ & & This work \\
\hline $\begin{array}{l}{\left[\mathrm{Ni}^{\mathrm{I}}\left(\mathrm{Me}_{6}[14] 4,11-\text { dieneN }_{4}\right)\right]^{+\mathrm{k}}} \\
\mathrm{MeCN} \\
\text { propylene carbonate }\end{array}$ & $\begin{array}{l}g_{\|}=2.226, g_{\perp}=2.055 \\
g_{\|}=2.220, g_{\perp}=2.063\end{array}$ & & $\begin{array}{l}20 \\
57\end{array}$ \\
\hline$n$-PrCN/EtCN 7:3 & $\begin{array}{l}57 \%: 2.256,2.060,2.042 \\
43 \%: 2.229,2.182,2.022\end{array}$ & & This work \\
\hline$\left[\mathrm{Ni}^{\mathrm{I}}\left(\mathrm{Me}_{6}[14] 4,11 \text {-dieneN }{ }_{4}\right)(\mathrm{CO})\right]^{+}$ & $2.201,2.123,2.018$ & & 57 \\
\hline $\begin{array}{l}{\left[\mathrm{Ni}^{\mathrm{I}}(\mathrm{tmc})\right]^{+1}} \\
n-\mathrm{PrCN} / \mathrm{EtCN} 7: 3\end{array}$ & $\begin{array}{l}69 \%: 2.352,2.220,2.032 \\
10 \%: 2.285,2.205,2.088 \\
21 \% 2.343,2.230,2.0061\end{array}$ & & This work \\
\hline
\end{tabular}


Table 1. Frozen solution EPR parameters for EPR-active MCR forms and tetraazamacrocyclic $\mathrm{Ni}^{\mathrm{I}}$ complexes (cont.)

\begin{tabular}{|c|c|c|c|}
\hline Complex, solvent & $\begin{array}{l}g \text { values } \\
\left(g_{\text {max }}, g_{\text {mid }}, g_{\text {min }}\right) \\
\end{array}$ & $A$ values $(\mathrm{MHz})$ & Reference \\
\hline $\begin{array}{l}{\left[\mathrm{Ni}^{\mathrm{I}}\left(\mathrm{Me}_{6}[14] \mathrm{aneN}_{4}\right)\right]^{+}} \\
\mathrm{MeCN} \\
\text { propylene carbonate }\end{array}$ & $\begin{array}{l}g_{\|}=2.266, g_{\perp}=2.055 \\
g_{\|}=2.253, g_{\perp}=2.054\end{array}$ & & $\begin{array}{l}20 \\
57\end{array}$ \\
\hline $\begin{array}{l}{\left[\mathrm{Ni}^{\mathrm{I}}\left(\mathrm{Me}_{6}[14] \mathrm{aneN}_{4}\right)(\mathrm{CO})\right]^{+}} \\
\text {propylene carbonate }\end{array}$ & $2.198,2.123,2.012$ & & 57 \\
\hline Complex, solvent & $\begin{array}{l}g \text { values } \\
\left(g_{\max }, g_{\text {mid }}, g_{\min }\right)\end{array}$ & $A$ values $(\mathrm{MHz})$ & Reference \\
\hline $\begin{array}{l}\left.\mathrm{Ni}^{\mathrm{I}}(\mathrm{tmc})\left(\mathrm{O}_{2}\right)\right]^{+} \\
\text {dmf/toluene 1:2 }\end{array}$ & $2.29,2.21,2.09$ & & 108 \\
\hline
\end{tabular}

${ }^{a}$ Red1 EPR signal present in the $\mathrm{MCR}_{\mathrm{red} 2}$ sample showing a mixture of red 2 and red1 signals; ${ }^{99}$ in the red 2 form, the $\mathrm{Ni}^{1}$ is coordinated by the thiol(ate) sulfur of coenzyme M ( $\left.\mathrm{HSCoM}=\mathrm{HSCH}_{2} \mathrm{CH}_{2} \mathrm{SO}_{3}{ }^{-}\right){ }^{36}{ }^{\mathrm{b}} \mathrm{Red} 1 \mathrm{EPR}$ signal in the presence of coenzyme M; this signal is referred to as $\mathrm{MCR}_{\text {redlc }}{ }^{\mathrm{c}}{ }^{\mathrm{Red} 1}$ EPR signal in the presence of methyl-coenzyme $\mathrm{M}\left(\mathrm{CH}_{3} \mathrm{SCH}_{2} \mathrm{CH}_{2} \mathrm{SO}_{3}{ }^{-}\right)$; this signal is referred to as $\mathrm{MCR}_{\text {redlm }} \cdot{ }^{\text {d }}$ Red1 EPR signal in the absence of other substrates, coenzymes, or other forms of MCR. This signal is denoted $\mathrm{MCR}_{\text {redla }}$, but simulation parameters for this specific form could not be found in the relevant references of Thauer and co-workers. ${ }^{99-101}$ e Red2 signal as originally reported; this is now referred to as $\mathrm{MCR}_{\text {redrr }}(\mathrm{r}=\mathrm{rhombic}$; there is also an axial red2 signal denoted $\mathrm{MCR}_{\text {red2a }}$, with EPR signals very similar to $\mathrm{MCR}_{\text {redla }}{ }^{25}$ Slightly different EPR parameters result depending on the two methods of generation of $\mathrm{MCR}_{\mathrm{red2} 2},{ }^{25}$ both parameter sets are given here. ${ }^{\mathrm{f}} \mathrm{Ox} 1$ signal as originally reported. Harmer et al. determined the full $\mathrm{A}\left({ }^{14} \mathrm{~N}\right)$ tensor for all four nitrogens of the macrocycle; ${ }^{24}$ the average, isotropic value of them all is given here for comparison with less refined data. In $\mathrm{MCR}_{\text {oxl }}$, there is formally a $\mathrm{Ni}^{\mathrm{III}}$ ion with thiolate ligation from $\mathrm{CoM}\left[\mathrm{Ni}^{\mathrm{II}}-\left(\mathrm{RS}^{-}\right)\right]$; this can also be considered as a spin-coupled $\mathrm{Ni}^{\mathrm{II}}$-thiyl system, $\left[\mathrm{Ni}^{\mathrm{II}}-\left(\mathrm{RS}^{\circ}\right)\right]$. $^{6 \mathrm{~g}^{\mathrm{g}}} \mathrm{Pentamethyl} \mathrm{ester}$ of $\mathrm{F}_{430}{ }^{33}$ h $\left(2,3,7,8\right.$-tetrahydro-2,3,7,8,12,13,17,18-octaethylporphyrin) $\mathrm{Ni}^{\mathrm{II}}$ (octaethylisobacteriochlorin) cryoreduced by $\gamma$-irradiation; the resulting $\mathrm{Ni}^{\mathrm{I}}$ species is heterogeneous, with several features that can be assigned to $g_{\|}$. The second entry is for the sample after brief ( $c a .5 \mathrm{~s}$ ) warming to $300 \mathrm{~K}$ under nitrogen. ${ }^{\mathrm{i}}$ (2,3-dihydro-2,3,7,8,12,13,17,18-octaethylporphyrin) $\mathrm{Ni}^{\mathrm{II}}$ (octaethylchlorin) chemically reduced by sodium tetracenide; the resulting $\mathrm{Ni}^{\mathrm{I}}$ species is unstable towards formation of a chlorin-phlorin anion. ${ }^{49} \mathrm{j}\left(2,3,7,8,12,13,17,18\right.$-octaethylporphyrin) $\mathrm{Ni}^{\mathrm{II}}$ cryoreduced by $\gamma$-irradiation; the $\mathrm{Ni}^{\mathrm{I}}$ signal disappears upon brief warming to $300 \mathrm{~K}$ under nitrogen. ${ }^{k}$ Mixture of meso and rac forms of $(5,7,7,12,14$, 14-hexamethyl-1,4,8,11-tetraazacyclotetradeca4,11-diene) $\mathrm{Ni}^{\mathrm{I}}$ perchlorate. ${ }^{58}$ The relative amount of the two isomers is unknown. ${ }^{1}$ Mixture of $R R S S$ and $R S R S$ isomeric forms of $(1,4,8,11$-tetramethyl1,4,8,11-tetraazacyclotetradecane) $\mathrm{Ni}^{\mathrm{I}}(\mathrm{tmc})$ trifluoromethylsulfonate. The relative amount of the two isomers is unknown, but is $c a$. 3:1 at equilibrium in aqueous solution. ${ }^{78 \mathrm{~m}}\left(C\right.$-meso-1,4,5,7,7,8,11,12,14,14-decamethyl-1,4,8,11-tetraazacyclotetradecane) $\mathrm{Ni}^{\mathrm{II}}\left(\mathrm{Me}_{6}[14] \mathrm{ane}(\mathrm{NMe})_{4}, \mathrm{Me}_{6}\right.$ tmc) reduced by steady-state radiolysis. ${ }^{79}$

of $\mathrm{MCR}_{\mathrm{red} 1}$ is shown in Figure 2, for both natural isotopic abundance and ${ }^{61} \mathrm{Ni}$-enriched samples. The EPR spectrum of the natural-abundance sample is almost the same as that for $\mathrm{Ni}^{\mathrm{I}} \mathrm{F}_{430}$, with $\mathbf{g}=[2.224,2.065,2.057]$, indicating that the electronic structure about the $\mathrm{Ni}^{\mathrm{I}}$ ion, including the nearly axial symmetry, is the same in the protein as in the isolated cofactor. In the enriched enzyme sample, hyperfine splitting due to ${ }^{61} \mathrm{Ni}(I=3 / 2)$ is apparent at $g_{\|}$, but is essentially unobservable at $g_{\perp}$. The use of ${ }^{61} \mathrm{Ni}$ thus yields an EPR spectrum for $\mathrm{MCR}_{\mathrm{red} 1}$ that resembles that for typical tetragonally distorted six-coordinate (square pyramidal, sq pyr) $\mathrm{Cu}^{\mathrm{II}}\left({ }^{63,65} \mathrm{Cu}, I=3 / 2,100 \%\right.$ abundance) with $d_{x z, y z}{ }^{4} d_{x y}{ }^{2} d_{z^{2}}{ }^{2} d_{x^{2}-y^{2}}$ configuration. The natural abundance $35 \mathrm{GHz}$ spectrum reveals very slight rhombic symmetry at $g_{\perp}$, but the resolution of the hyperfine splitting at $g_{\|}$in the enriched sample is less than ideal. However, X-band EPR provides good resolution of $A\left({ }^{61} \mathrm{Ni}\right)_{\|}=200(10) \mathrm{MHz}$, equivalent to the value reported elsewhere. ${ }^{99,101}$ This result is analogous to the improved resolution at X-band compared to $35 \mathrm{GHz}$ of ${ }^{14} \mathrm{~N}$ hyperfine described above for $\mathrm{Ni}^{\mathrm{I}} \mathrm{F}_{430}$ and $\left[\mathrm{Ni}^{\mathrm{I}}(\mathrm{OEiBC})\right]^{-}$. The chief difference between the ${ }^{61} \mathrm{Ni}$-enriched spectrum for $\mathrm{MCR}_{\text {red1 }}$ and that for typical $\mathrm{Cu}^{\text {II }}$ tetrapyrroles is the larger magnitude hyperfine coupling in the latter $\left(\right.$ e.g., $A\left({ }^{63} \mathrm{Cu}\right)_{\|}=630 \mathrm{MHz}$ for $\left.[\mathrm{Cu}(\mathrm{OEP})]^{98}\right)$. This three-fold larger $A$ value in the $\mathrm{Cu}^{\mathrm{II}}$ complex is largely the consequence of the three-fold larger $g_{\mathrm{N}}$ for $\mathrm{Cu}\left({ }^{63} \mathrm{Cu}, g_{\mathrm{N}}=1.484 ;{ }^{65} \mathrm{Cu}, g_{\mathrm{N}}=1.588\right)$ versus ${ }^{61} \mathrm{Ni}$ $\left(g_{\mathrm{N}}=-0.500\right),{ }^{5}$ so that the bonding in the two complexes is actually quite similar $\left(A / g_{\mathrm{N}}=400\right.$ for ${ }^{61} \mathrm{Ni} ; 424$ for $\left.{ }^{63} \mathrm{Cu}\right)$. Indeed, the $\mathrm{M}-\mathrm{N}$ bond distances are also quite similar. The $\mathrm{Cu}^{\mathrm{II}}-\mathrm{N}$ distances in $[\mathrm{Cu}(\mathrm{OEP})]$ are $199.6(3) \mathrm{pm}$ $(\mathrm{Cu}-\mathrm{N}(1))$ and $199.9(3) \mathrm{pm}(\mathrm{Cu}-\mathrm{N}(2)),{ }^{104}$ while the EXAFS-determined $\mathrm{Ni}^{\mathrm{I}}-\mathrm{N}$ distances in $\left[\mathrm{Ni}^{\mathrm{I}}(\mathrm{OEiBC})\right]^{-}$are two at $191 \mathrm{pm}$ and two at $207 \mathrm{pm},{ }^{45}$ and for $\mathrm{Ni}^{\mathrm{I}} \mathrm{F}_{430} \mathrm{M}$, two at $188 \mathrm{pm}$ and two at $203 \mathrm{pm} .{ }^{40}$ It is unfortunate that cost precludes ${ }^{61} \mathrm{Ni}$ hyperfine coupling data from being more available for $\mathrm{Ni}^{\mathrm{I}}$ complexes in general, but the EPR results for $\mathrm{MCR}_{\text {red1 }}$ clearly show that this species, and by extension, isolated $\mathrm{Ni}^{\mathrm{I}} \mathrm{F}_{430}$, whether in aqueous or organic solvent, and $\left[\mathrm{Ni}^{\mathrm{I}}(\mathrm{OEiBC})\right]^{-}$, are all typical tetragonally distorted (whether square planar (sq pl), square pyramidal, or even six-coordinate, is not significant) $d_{x y, x z, y z, z^{2}} d_{x^{2}-y^{2}}$ complexes, such as commonly found for $\mathrm{Cu}^{\mathrm{II}}$ with tetrapyrroles and related ligands. 


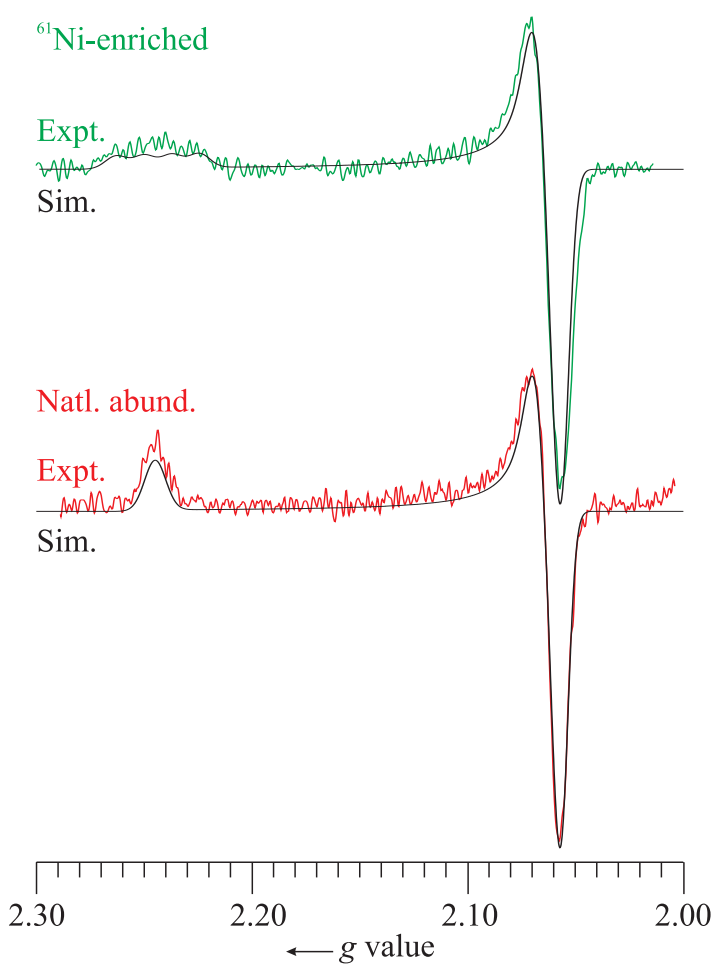

Figure 2. Experimental (dashed trace of pair (colored in online version)) and simulated (solid black trace of pair) $35 \mathrm{GHz}$ EPR spectra of $\mathrm{MCR}_{\text {red } 1}$ in natural isotopic abundance and ${ }^{61} \mathrm{Ni}$-enriched. The spectra were recorded at $2 \mathrm{~K}$ using the dispersion mode under passage conditions; a numerical first derivative is shown. The abscissa is in $g$ value to facilitate comparison between spectra recorded at different frequencies (35.035 for natural abundance; $34.945 \mathrm{GHz}$ for ${ }^{61} \mathrm{Ni}$-enriched). The simulation parameters are $\mathbf{g}=[2.224,2.065,2.057], W=90 \mathrm{MHz}$ (single crystal Gaussian linewidths, hwhm); the enriched sample includes: $A\left({ }^{61} \mathrm{Ni}\right) g_{\max }=200 \mathrm{MHz}$.

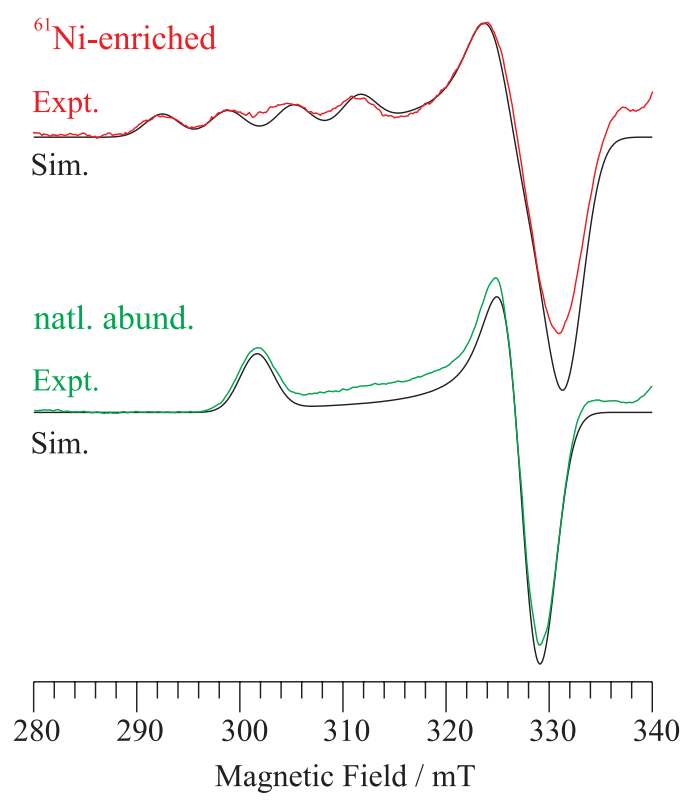

Figure 3. Experimental (dashed trace of pair (colored in online version)) and simulated (solid black trace of pair) X-band $(9.47 \mathrm{GHz}) \mathrm{EPR}$ spectra recorded at $77 \mathrm{~K}$ of $\mathrm{MCR}_{\text {red } 1}$ in natural isotopic abundance and ${ }^{61} \mathrm{Ni}$-enriched. The simulation parameters are as in Figure 2, except $W=60 \mathrm{MHz}$.

\section{5. $35 \mathrm{GHz}$ EPR spectra of $\left[\mathrm{Ni}^{\mathrm{I}}\left(\mathrm{Me}_{6}[14] 4,11 \text {-dieneN }{ }_{4}\right)\right]^{+}$}

The complex $\left[\mathrm{Ni}^{\mathrm{I}}\left(\mathrm{Me}_{6}[14] 4,11-\right.\right.$ dieneN $\left.\left._{4}\right)\right]\left(\mathrm{ClO}_{4}\right)$ represents a step away from $\pi$-conjugation relative to the species discussed above. It is one of the few $\mathrm{Ni}^{\mathrm{I}}$ complexes to be crystallographically characterized (in the racemic form) and was thus used for bond distance calibration in EXAFS studies of $\mathrm{Ni}^{\mathrm{I}}$ species for which no crystal structures were available $\left(e . g ., \mathrm{Ni}^{\mathrm{l}} \mathrm{F}_{430}\right){ }^{58} \mathrm{It}$ is also representative of the many tetraaza macrocyclic complexes described by Busch and co-workers. ${ }^{20}$ The X-band spectrum of this electrochemically generated complex in propylene carbonate frozen solution was reported by Gagné and Ingle ${ }^{57}$ and gave $g_{\|}=2.220, g_{\perp}=2.063$. As can be seen from Table 1 , these values are totally unremarkable, and indeed, are almost the same as those for the $\mathrm{Ni}^{\mathrm{I}}$ species described in the preceding sections. Here, however, a mixed nitrile solvent system was used ( $n$-butyronitrile/ propionitrile, 7:3 v/v), which provides a good glass for EPR. This nitrile solvent system is effective at dissolving the ionic complex and nitriles would be expected to be relatively weak donors, compared to, e.g., $\mathrm{CO}$, the binding of which had been extensively studied in $\mathrm{Ni}^{1}$ complexes. ${ }^{57}$ Nevertheless, an EPR spectrum quite different from that of the $\mathrm{Ni}^{\mathrm{I}}$ species discussed hitherto results, as shown in Figure 4 . The signal is clearly heterogeneous, and can be adequately described as the superposition in roughly equal amounts of two signals, one described by $\mathbf{g}=[2.256$, $2.060,2.042]$, and one with $\mathbf{g}=[2.229,2.182,2.022]$. The former, nearly axial $\mathbf{g}$ matrix, while different from those previously reported ${ }^{20,57}$ is nevertheless similar to that for the other tetragonal $\mathrm{Ni}^{\mathrm{I}}$ complexes described herein (Table 1). The better field dispersion of $35 \mathrm{GHz}$ EPR might allow resolution of rhombic splitting that was not observable in the earlier X-band studies, ${ }^{20,57}$ and the difference in solvent might be responsible for the other differences - note the variation in $g$ values among the various forms of $\mathrm{MCR}_{\text {redl }}$ and of $\mathrm{Ni}^{\mathrm{l}} \mathrm{F}_{430}-$ all in aqueous solvent (Table 1). Note also that the crystal structure of meso-[ $\left[\mathrm{Ni}^{\mathrm{I}}\left(\mathrm{Me}_{6}[14] 4,11\right.\right.$ dieneN $\left.\left.{ }_{4}\right)\right]\left(\mathrm{ClO}_{4}\right)$ shows a planar $\mathrm{NiN}_{4}$ unit with two sets of $\mathrm{Ni}-\mathrm{N}$ bond distances,${ }^{58}$ which would be expected to give a slightly rhombic, tetragonal type $\left(g_{\|} c a .2 .2>g_{\perp} c a .2 .05\right)$ of EPR signal. The EPR signal with the axial $\mathbf{g}$ is thus assigned to a typical, tetragonal $\mathrm{Ni}^{\mathrm{I}}$ tetraaza macrocycle: $d_{x z, y z}{ }^{4} d_{x y}{ }^{2} d_{z^{2}} d_{x^{2}-y^{2}}$; sq pl in the absence of any axial ligand (from solvent) coordination; five-coordinate with one axial ligand; six-coordinate with two, all analogous to $\mathrm{Cu}^{\mathrm{II}}$ complexes of the same geometry.

What about the rhombic signal? Such a signal is similar to that seen for $\mathrm{MCR}_{\mathrm{red} 2}: \mathbf{g}=[2.2940,2.2385,2.1790] .{ }^{99}$ In this MCR form, there is an axial sulfur donor (from 
coenzyme $\mathrm{M}$ ) to the $\mathrm{Ni}^{\mathrm{I}}$ ion. ${ }^{25,36}$ Perhaps more relevant, exposure to $\mathrm{CO}$ leads to formation of $\left[\mathrm{Ni}^{\mathrm{I}}\left(\mathrm{Me}_{6}[14] 4,11\right.\right.$ dieneN $\left.\left.{ }_{4}\right)(\mathrm{CO})\right]^{+}$with $\mathbf{g}=[2.201,2.123,2.018] .{ }^{57}$ One could propose therefore, that the highly rhombic signal observed for $\left[\mathrm{Ni}^{\mathrm{I}}\left(\mathrm{Me}_{6}[14] 4,11-\text { dieneN } \mathrm{N}_{4}\right)\right]^{+}$results from axial coordination by a nitrile involving $\pi$-donation from $\mathrm{Ni}^{\mathrm{I}}$ to the axial ligand, as with $\mathrm{Ni}^{\mathrm{I}}-\mathrm{CO}$ bonding. That a nitrile could have this effect would be a statement as to the powerful $\pi$-donor abilities of $\mathrm{Ni}^{\mathrm{I}}$, which is related to its nucleophilic role in MCR action. However, previous EPR studies on $\mathrm{Ni}^{\mathrm{I}}$ complexes showed no such behavior in acetonitrile solvent. ${ }^{20}$ It is apparently the case here that the flexible macrocyclic ligand, whether the cause or effect of nitrile binding, adopts a conformation that is highly distorted from square planar tetraaza (overall square pyramidal due to one axial nitrile, $\mathrm{CO}$, thiol(ate) etc), becoming trigonal bipyramidal (tbp) in the extreme case. For ideal tbp geometry, which for $\mathrm{d}^{9}$ has the electronic configuration $d_{x z, y z}{ }^{4} d_{x y, x^{2}-y^{2}}{ }^{4} d_{z^{2}}{ }^{1}$, the $g$ values are: $g_{\|} \cong 2.00<$ $g_{\perp} \cong 2.25(5) .{ }^{105,106} \mathrm{Such}$ an axial signal is not seen here, but the lower symmetry present in these $\mathrm{Ni}^{\mathrm{I}}$ complexes is unlikely ever to yield ideal tbp geometry.

What about intermediate geometries? This situation is much more complicated, but has been beautifully worked out using ligand-field theory by Bencini and coworkers. ${ }^{105,106}$ This theoretical work was in conjunction with their EPR studies on bis( $N$-methylsalicylaldiminato) complexes of $\mathrm{Cu}^{\mathrm{II}}$, which quinquidentate ligand strongly favors tbp coordination geometry. Bencini et al. ${ }^{105,106}$ provided equations for the $\mathbf{g}$ tensor components for the entire transition from square pyramidal to tbp in $C_{2 v}$ symmetry. They explain (especially see Figure 4 in Bencini et al. ${ }^{106}$ ) that this change causes $g_{\max }\left(g_{z}\right)$ slightly to decrease from roughly 2.30 to $2.20 ; g_{\min }\left(g_{x}\right)$ likewise decreases also only slightly, from 2.07 to 2.00 ; however $g_{\text {mid }}\left(g_{y}\right)$ varies significantly during this transition, from roughly 2.07 to 2.22 .

Such a geometry that approaches tbp could thus be proposed for the second species in $\left[\mathrm{Ni}^{\mathrm{I}}\left(\mathrm{Me}_{6}[14] 4,11\right.\right.$ diene $\left.\left.\mathrm{N}_{4}\right)\right]^{+}$, that with $\mathbf{g}=[2.229,2.182,2.022]$; this $\mathbf{g}$ could correspond approximately to $\alpha \mathrm{ca} .115^{\circ}$, where $90^{\circ}$ (sq pyr) $\leq \alpha \leq 120^{\circ}$ (tbp). Equations for $\mathrm{A}\left({ }^{63,65} \mathrm{Cu}\right)$ were also given, ${ }^{106}$ which should be applicable to ${ }^{61} \mathrm{Ni}$. Unfortunately, there are no $A\left({ }^{61} \mathrm{Ni}\right)$ data to which to apply the Bencini model except for $\mathrm{MCR}_{\text {red } 1}$, which fits their model of a typical tetragonal/square pyramidal system. One would expect that ${ }^{61} \mathrm{Ni}$-enriched $\left[\mathrm{Ni}^{\mathrm{I}}\left(\mathrm{Me}_{6}[14] 4,11 \text {-dieneN }{ }_{4}\right)\right]^{+}$would show large $(c a .200 \mathrm{MHz}){ }^{61} \mathrm{Ni}$ hyperfine coupling at $g_{\max }\left(g_{z}\right)$ for the axial (sq pyr) signal and smaller for the rhombic (tbp) signal. We further speculate that the rac form corresponds to the rhombic EPR signal, as this form binds $\mathrm{CO},{ }^{57,58}$ while

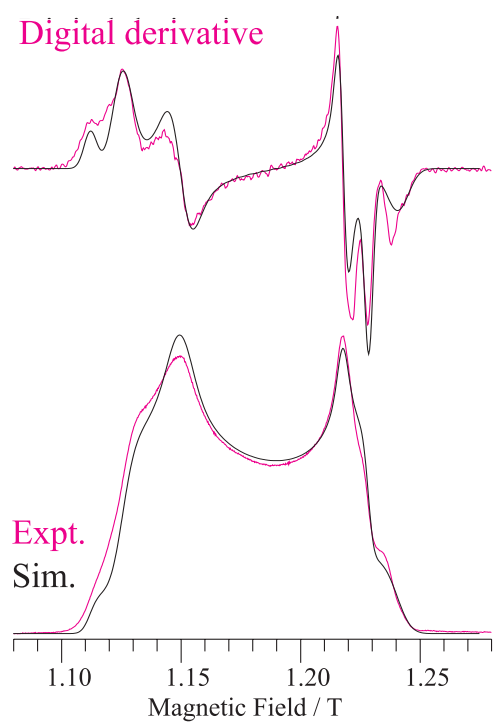

Figure 4. Experimental (dashed trace (colored in online version)) and simulated (solid black trace) $35 \mathrm{GHz}$ EPR spectrum of $\left[\mathrm{Ni}^{\mathrm{I}}\left(\mathrm{Me}_{6}[14] 4,11-\right.\right.$ dieneN $\left.\left.\mathrm{N}_{4}\right)\right]\left(\mathrm{ClO}_{4}\right)$ in $n$-butyronitrile/propionitrile $(7: 3 \mathrm{v} / \mathrm{v})$ frozen solution. The spectrum was recorded at $2 \mathrm{~K}$ (and $35.116 \mathrm{GHz}$ ) using the dispersion mode under passage conditions; both the experimental absorption lineshape (lower dashed (colored) trace) and a digital first derivative (upper dashed (colored) trace) are shown with their simulations. The simulation is the sum of two parameter sets: $57 \%$ integrated intensity weighting using $\mathbf{g}=[2.256$, $2.060,2.042], W=[100,60,60] \mathrm{MHz}$ (single crystal Gaussian linewidths, hwhm); $43 \%$ weighting using $\mathbf{g}=[2.229,2.182,2.022], W=150 \mathrm{MHz}$.

the meso form corresponds to the axial EPR signal, similar to the structurally characterized form.

\section{6. $35 \mathrm{GHz}$ EPR spectra of $\left[\mathrm{Ni}^{I}(\mathrm{tmc})\right]^{+}$}

The final, stable $\mathrm{Ni}^{\mathrm{I}}$ species to be described here is that with the fully saturated tetraaza macrocyclic ligand, tmc. The crystal structure of $R R S S-\left[\mathrm{Ni}^{\mathrm{I}}(\mathrm{tmc})\right]$ $\left(\mathrm{CF}_{3} \mathrm{SO}_{3}\right) \cdot \mathrm{NaCF}_{3} \mathrm{SO}_{3}$ shows that the geometry around the $\mathrm{Ni}^{\mathrm{I}}$ ion is exactly planar with two sets of $\mathrm{Ni}-\mathrm{N}$ bond distances (209.5 and $212.0 \mathrm{pm}),{ }^{76}$ analogous to the results for $\left[\mathrm{Ni}^{\mathrm{I}}(\mathrm{OEiBC})\right]^{-}$. The EPR spectrum of $\left[\mathrm{Ni}^{\mathrm{I}}(\mathrm{tmc})\right]^{+}$has not, to our knowledge, been previously reported. However, the spectra for other fully saturated tetraaza macrocyclic complexes of electrochemically generated $\mathrm{Ni}^{\mathrm{I}}$ have been reported, such as with $\mathrm{Me}_{2}[14] \operatorname{aneN}_{4}\left(g_{\|}=2.261\right.$, $\left.g_{\perp}=2.060\right)$ and $\mathrm{Me}_{6}[14] \operatorname{aneN}_{4}\left(g_{\|}=2.266, g_{\perp}=2.055\right.$ in acetonitrile solution; $g_{\|}=2.253, g_{\perp}=2.054$ in propylene carbonate solution). ${ }^{20,57}$ These EPR parameters are again very similar to many other such tetragonal/sq pyr/sq pl complexes (see Table 1).

In contrast to these clear-cut, earlier results, the $35 \mathrm{GHz}$ EPR spectrum of $\left[\mathrm{Ni}^{\mathrm{I}}(\mathrm{tmc})\right]^{+}$in the nitrile solvent system is heterogeneous. As shown in Figure 5, the spectrum can be deconvoluted into at least two components, or better with three. Two components are expected since, although the solution was prepared from solid RRSS isomer, in solution there is 


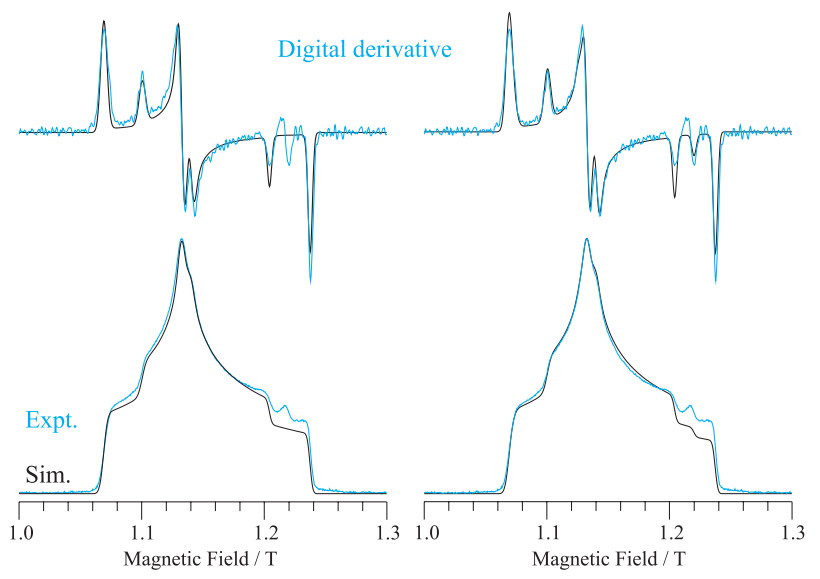

Figure 5. Experimental (dashed trace (colored in online version)) and simulated (solid black trace) $35 \mathrm{GHz}$ EPR spectrum of RRSS-[Ni(tmc)] $\left(\mathrm{CF}_{3} \mathrm{SO}_{3}\right) \cdot \mathrm{NaCF}_{3} \mathrm{SO}_{3}$ in $n$-butyronitrile/propionitrile $(7: 3 \mathrm{v} / \mathrm{v})$ frozen solution. The spectrum was recorded at $2 \mathrm{~K}$ (and $35.198 \mathrm{GHz}$ ) using the dispersion mode under passage conditions; both the experimental absorption lineshape (lower dashed (colored) trace) and a digital first derivative (upper dashed (colored) trace) are shown with their simulations. In the left panel, the simulation is the sum of two parameter sets: $87 \%$ integrated intensity weighting using $\mathbf{g}=[2.352,2.220,2.032], 13 \%$ weighting using $\mathbf{g}=[2.285,2.205,2.088]$, for both $W=[100,80,60] \mathrm{MHz}$ (single crystal Gaussian linewidths, hwhm). In the right panel, 69\% weighting using $\mathbf{g}=[2.352,2.220,2.032], 10 \%$ using $\mathbf{g}=[2.285,2.205,2.088]$, and $21 \%$ using $\mathbf{g}=[2.343,2.230,2.0061]$, for all $W=[100,80,60] \mathrm{MHz}$.

inter conversion so that the RSRS isomer is also present. ${ }^{76,78}$ The relative amount of the two isomers in nitrile solutions is unknown, but at equilibrium is $c a .3: 1$ in aqueous solution, ${ }^{78}$ so that the deconvolution into $69 \%$ major component and $31 \%$ two minor components is not that far off from the aqueous solution result. However, these three EPR components are all highly rhombic and none resembles typical tetraaza macrocyclic complexes of $\mathrm{Ni}^{\mathrm{I}}$ (i.e., $\mathrm{Cu}^{\mathrm{II}}$-like parameters: $g_{\|} \cong 2.25(5), g_{\perp} \cong 2.05(5)$; see Table 1 ), as would be expected from the crystal structure. A possible explanation is that axial coordination of the nitrile ligand leads to formation of species that are electronically very similar to the $\mathrm{CO}$ adducts of the $\mathrm{Ni}^{\mathrm{I}}$ macrocycles reported by Gagné and Ingle ${ }^{57}$ This possibility was raised above to explain the rhombic component in the EPR spectrum of $\left[\mathrm{Ni}^{\mathrm{l}}\left(\mathrm{Me}_{6}[14] \mathrm{aneN}_{4}\right)\right]^{+}$(Figure 4). It is surprising, however, that butyronitrile/propionitrile would behave as the strong $\pi$-acceptor CO does. Furthermore, although Gagné and Ingle used the polar, but totally non-coordinating solvent propylene carbonate, ${ }^{57}$ acetonitrile was employed earlier by Lovecchio, Gore, and Busch, ${ }^{20}$ and their spectra differ only trivially from the corresponding spectra reported by Gagné and Ingle. ${ }^{57}$ The rhombic signals seen for $\left[\mathrm{Ni}^{1}(\mathrm{tmc})\right]^{+}$also strongly resemble those for $\mathrm{MCR}_{\text {red2 } 2}{ }^{36,99}$ however, these result from an axial thiolate ligand (from coenzyme $\mathrm{M}$ ) to $\mathrm{Ni}^{\mathrm{I}}$, and no such species is available in the present case. Meyerstein and co-workers ${ }^{79,80}$ used radiolysis, as well as electrochemistry, to generate tetraaza macrocyclic complexes of $\mathrm{Ni}^{\mathrm{I}}$ from $\mathrm{Ni}^{\mathrm{II}}$ in aqueous solution. They reported EPR spectra at $77 \mathrm{~K}$ of radiolytically generated $\left[\mathrm{Ni}^{\mathrm{I}}\left(\mathrm{Me}_{6} \mathrm{tmc}\right)\right]^{+}$that were typical for a tetragonal complex $\left(g_{\|}=2.333, g_{\perp}=2.069\right.$; see Table 1); however, in the presence of formate ion, highly rhombic spectra were observed: $\mathbf{g}=[2.261,2.136,2.073] .{ }^{79}$ No explanation for this was given.

Our speculation for the EPR behavior of $\left[\mathrm{Ni}^{\mathrm{I}}(\mathrm{tmc})\right]^{+}$in nitrile frozen solution, and possibly the results of Jubran $e t$ $a l .{ }^{79}$ is the same as that given above for $\left[\mathrm{Ni}^{\mathrm{I}}\left(\mathrm{Me}_{6}[14] 4,11\right.\right.$ diene $\left.\left.\mathrm{N}_{4}\right)\right]^{+}$, namely that there is distortion away from sq $\mathrm{pl}$ or sq pyr (with axial nitrile) geometry towards either distorted tetrahedral or tbp geometry (with equatorial nitrile), which leads to mixing in of $d_{z^{1}}{ }^{1}$ character into the ground state. The difference among the three forms seen by EPR is relatively slight; we can only speculate the one form corresponds to one isomer in a given geometry, whether distorted tetrahedral or tbp (due to nitrile coordination), and the other two to the other isomer in each of these geometries (or tbp with both axial and equatorial nitrile coordination).

\subsection{Discussion of “nickel(I)-dioxygen" species}

Solution samples of the $\mathrm{Ni}^{\mathrm{I}}$ complexes that were provided as solids, meso, $r a c-\left[\mathrm{Ni}^{\mathrm{I}}\left(\mathrm{Me}_{6}[14] \mathrm{aneN}_{4}\right)\right]^{+}$and $R R S S-\left[\mathrm{Ni}^{\mathrm{I}}(\mathrm{tmc})\right]^{+}$, were prepared under inert atmosphere. However, the possibility that some amount of dioxygen adducts were formed cannot be totally excluded. We therefore summarize here very interesting and recent studies by Riordan and co-workers ${ }^{107}$ on dioxygen binding to $\mathrm{Ni}^{\mathrm{I}}$ complexes, including $R R S S-\left[\mathrm{Ni}^{\mathrm{I}}(\mathrm{tmc})\right]^{+}$in a variety of solvents (e.g., MeCN, thf, dmf and $\mathrm{MeOH}) .{ }^{108} \mathrm{~A}$ complex they formulated as $\left[\mathrm{Ni}(\mathrm{tmc})\left(\mathrm{O}_{2}\right)\right]^{+}$exhibited a rhombic EPR signal (X-band, $14 \mathrm{~K}$ ) with $\mathbf{g}=[2.29,2.21,2.09],{ }^{108}$ which is remarkably similar to those for $\mathrm{CO}$ adducts of $\mathrm{Ni}^{\mathrm{I}}$ tetraaza macrocycles ${ }^{57}$ However, a wide variety of other physical techniques were used to characterize this dioxygen complex in solution, including UV-Vis, XAS, and Resonance Raman spectroscopy. Such a species can have multiple descriptions: $\left[\mathrm{Ni}^{\mathrm{I}}-\mathrm{O}_{2}{ }^{0}\right]^{+}$(dioxygen), $\left[\mathrm{Ni}^{\mathrm{II}}-\mathrm{O}_{2}{ }^{-}\right]^{+}$(superoxo), or $\left[\mathrm{Ni}^{\mathrm{III}}-\mathrm{O}_{2}{ }^{2-}\right]^{+}$(peroxo), which we will evaluate here.

The $\mathrm{Ni}^{\mathrm{III}}$-peroxo formulation would be expected to give EPR spectra typical of such low-spin $3 \mathrm{~d}^{7}$ complexes (for tetraaza macrocyclic complexes of $\mathrm{Ni}^{\mathrm{III}}: g_{\|} \cong 2.02(2)$, $\left.g_{\perp} \cong 2.20(2)^{20,109}\right)$, which is similar to that of [ $\mathrm{Ni}(\mathrm{tmc})$ $\left.\left(\mathrm{O}_{2}\right)\right]^{+}\left(g_{\|}=2.09, g_{\perp}=2.25(4)\right)$. The EPR spectrum of $\left[\mathrm{Ni}(\mathrm{tmc})\left(\mathrm{O}_{2}\right)\right]^{+}$is optimal at low temperature $(6 \mathrm{~K})$ and decreases with higher temperature (see Figure S9 in Kieber-Emmons et al. ${ }^{108}$ ). In contrast, EPR spectra for authentic $\mathrm{Ni}^{\mathrm{III}}$ complexes are readily observed even at room temperature. ${ }^{109}$ This suggests to us that the $\mathrm{Ni}^{\text {III- }}$ peroxo description (which was disfavored based on other 
techniques ${ }^{108}$ ) is not reasonable, even thought the $g$ values are possible for $\mathrm{Ni}^{\mathrm{iII}}$.

The $\mathrm{Ni}^{\mathrm{II}}$-superoxo formulation is more complicated, as there are two possible spin states for $\mathrm{Ni}^{\mathrm{II}}$, and two modes of magnetic exchange coupling. Nickel(II) can be described as $S=1$, such as found in octahedral $\mathrm{Ni}^{\mathrm{II}}$ complexes, ${ }^{110}$ or it could be described as $S=0$, such as found in sq $\mathrm{pl} \mathrm{Ni}^{\mathrm{II}}$ complexes. In the first case, $S=1 \mathrm{Ni}^{\mathrm{II}}$ would be antiferromagnetically coupled to $S=1 / 2 \mathrm{O}_{2}^{-}$, to give a total spin $S_{\text {tot }}=1 / 2$ ground state. ${ }^{108}$ Another possibility is ferromagnetic coupling between the two centers to give $S_{\text {tot }}=3 / 2$. Ferromagnetic coupling between $S=1 / 2 \mathrm{Cu}^{\mathrm{II}}$ and $S=1 / 2 \mathrm{O}_{2}^{-}$to give $S_{\text {tot }}=1$ has been proposed to describe a copper-dioxygen species. ${ }^{111}$ The observed EPR spectrum for $\left[\mathrm{Ni}(\mathrm{tmc})\left(\mathrm{O}_{2}\right)\right]^{+}$, however, would be very difficult to describe as arising from $S=3 / 2$; the fine structure transitions would have to masquerade perfectly as $g$ value anisotropy. The possibility of $S=0 \mathrm{Ni}^{\mathrm{II}}$, with the paramagnetic center being essentially the $S=1 / 2 \mathrm{O}_{2}^{-}$, can be ruled out by the EPR spectra of $\left[\mathrm{Ni}(\mathrm{tmc})\left({ }^{17} \mathrm{O}_{2}\right)\right]^{+}$, which showed line broadening of ca. $1 \mathrm{mT} .{ }^{108}$ In contrast, superoxide ion bound to diamagnetic centers exhibits hyperfine coupling from ${ }^{17} \mathrm{O}$ that can be quite large. The hyperfine coupling of superoxide is very anisotropic $\left(\mathrm{A}\left({ }^{17} \mathrm{O}\right)=[-7.636,0.718,0.824] \mathrm{mT}\right),{ }^{112}$ but the largest magnitude component is diagnostic of metal superoxide binding. ${ }^{113}$ To give an example of a metal tetrapyrrole complex, we note that for an unusual oxy-hemoglobin (oxy-GMH3 from Glycera dibranchiata), a maximal ${ }^{17} \mathrm{O}$ hyperfine coupling of $7.5 \mathrm{mT}$ was seen, thus the paramagnetic species is best described as low-spin $\mathrm{Fe}^{\mathrm{II}}\left(3 \mathrm{~d}^{6}, S=0\right)$ bound to superoxide. ${ }^{90}$

What about the $\left[\mathrm{Ni}^{\mathrm{I}}-\mathrm{O}_{2}{ }^{0}\right]^{+}$formulation? This could be described as $S=1 / 2 \mathrm{Ni}^{\mathrm{I}}$ antiferromagnetically coupled to $S=1 \mathrm{O}_{2}{ }^{0}$, to give a total spin $S_{\text {tot }}=1 / 2$ ground state. Such a species would not be expected to give the large magnitude ${ }^{17} \mathrm{O}$ hyperfine coupling of an authentic (i.e., uncoupled) superoxide ion. Furthermore, $\mathrm{Ni}^{\mathrm{I}}$ tetraaza macrocycles reversibly bind $\mathrm{CO}$ to give what could hardly be described as anything other than $\left[\mathrm{Ni}^{\mathrm{I}}-\mathrm{CO}^{0}\right]^{+}$, and these $\mathrm{CO}$ adducts exhibit EPR spectra that are essentially the same as that for $\left[\mathrm{Ni}(\mathrm{tmc})\left(\mathrm{O}_{2}\right)\right]^{+}$. Relaxation effects in antiferromagnetically coupled systems, whether $\mathrm{Ni}^{\mathrm{I}-}-\mathrm{O}_{2}{ }^{0}$ or $\mathrm{Ni}^{\mathrm{II}}-\mathrm{O}_{2}^{-}$, could be very effective due to the number of low-lying excited states, which would preclude observation of EPR spectra except at low temperatures. Thus the EPR temperature dependence might not allow distinguishing between these two possibilities. Nevertheless, given the highly reduced nature of $\mathrm{Ni}^{\mathrm{I}}$, maintaining $\mathrm{Ni}^{\mathrm{I}}$ and $\mathrm{O}_{2}{ }^{0}$ oxidation states seems unlikely. Formal oxidation to $\mathrm{Ni}^{\mathrm{II}}$ is supported by XAS for both $\left[\mathrm{Ni}(\mathrm{tmc})\left(\mathrm{O}_{2}\right)\right]^{+}$and a dioxygen complex of $\mathrm{Ni}^{\mathrm{I}}$ with the tripodal-thioether ligand (phenyl[tris(alkylthiomethyl)] borate, where alkyl $=t$-butyl or adamantyl). ${ }^{107}$ Riordan and co-workers ${ }^{107}$ have proposed that all of their $\mathrm{Ni}^{\mathrm{I}}$-dioxygen complexes are best described as ( $\left.\mathrm{Ni}^{\mathrm{II}}, S=1\right)-\mathrm{O}_{2}^{-}$, and this seems to be the ideal model in general.

\section{8. $35 \mathrm{GHz}$ EPR Spectra of $\gamma$-irradiated [Nil $(\mathrm{OEiBC})]$}

$\mathrm{Ni}(\mathrm{OEiBC})$ and $\mathrm{Ni}(\mathrm{OEP})$ in 2-Methf solution are EPR silent, as expected for these $\mathrm{Ni}^{\mathrm{II}}$ complexes with sq $\mathrm{pl}$ (solid state) or sq pyr (in the presence of coordinating solvent) geometries. Stolzenberg and Stershic, ${ }^{49}$ in an extensive study of a wide variety of $\mathrm{Ni}^{\mathrm{II}}$ tetrapyrroles, showed that chemical or electrochemical reduction of $\mathrm{Ni}(\mathrm{OEP})$ yields an unstable ligand-centered product $\left[\mathrm{Ni}^{\mathrm{II}}\left(\mathrm{OEP}^{*}\right)\right]^{-}$(a weak EPR signal at $g=2.00$ was observed under certain conditions) that undergoes further reduction of disproportionation to give a stable, diamagnetic phlorin anion complex. For $\mathrm{Ni}(\mathrm{OEC})$, a chlorin-phlorin also results, but a bona fide $\mathrm{Ni}^{\mathrm{I}}$ EPR signal can be initially observed (see Table 1$).{ }^{49}$ Only $\mathrm{Ni}(\mathrm{OEiBC})$ affords chemical reduction products that are stable in solution, as discussed above.

The difficulty faced by Stolzenberg et al..$^{46-49}$ in these studies was the necessity of working in fluid solution; otherwise chemical or electrochemical reduction cannot occur. Another approach is to effect reduction in frozen solution $(77 \mathrm{~K})$; this is possible by use of $\gamma$-irradiation, which ejects electrons from the solvent medium. ${ }^{82,84,89-91} \mathrm{We}$ applied this technique to both $\mathrm{Ni}(\mathrm{OEiBC})$ and $\mathrm{Ni}(\mathrm{OEP})$ in 2-Methf at $77 \mathrm{~K}$; unfortunately, $\mathrm{Ni}(\mathrm{OEC})$ was not available to us. Figure 6 presents the $35 \mathrm{GHz}$ EPR spectrum of $t t t-$ $\mathrm{Ni}(\mathrm{OEiBC})$ after $\gamma$-irradiation. A large signal at $g=2.00$ is not shown. This signal results from organic radicals produced from the solvent, although it might also include radicals derived from ligand-centered reduction as well. There is also a sharp peak at $1.235 \mathrm{~T}$ that is one partner of the hyperfine split spectrum of the $\mathrm{H}$ atom. ${ }^{5}$ The presence of this peak (and its upfield partner, not shown) is proof that no radical recombination (or other such processes related to molecular motion) has occurred - if there is any molecular motion, then the $\mathrm{H}$ atoms react readily and the characteristic signal disappears. ${ }^{82,84,89-91}$ At lower field, however, there are signals that are clearly due to $\mathrm{Ni}^{\mathrm{I}}$. More than one signal is present, as there is a perpendicular feature at $g_{\perp}=2.075$, and several parallel features at $g_{\|}=2.11,2.18$, and 2.30. Due to the complexity of the pattern and the large radical signal, no attempt was made to simulate the spectrum. It is possible that additional $g_{\perp}$ feature(s) exist at higher field, but are obscured by the large radical signal. The multiple signals indicate that there are multiple species in frozen solution which, since there was no motion upon reduction, arise from multiple conformation of the $\mathrm{Ni}^{\mathrm{iI}}$ parent complex. As discussed by many researchers, ${ }^{51,55,56,69,114,115} \mathrm{Ni}^{\text {II }}$ tetrapyrroles are highly flexible (towards ruffling, saddling etc) and the heterogeneity 


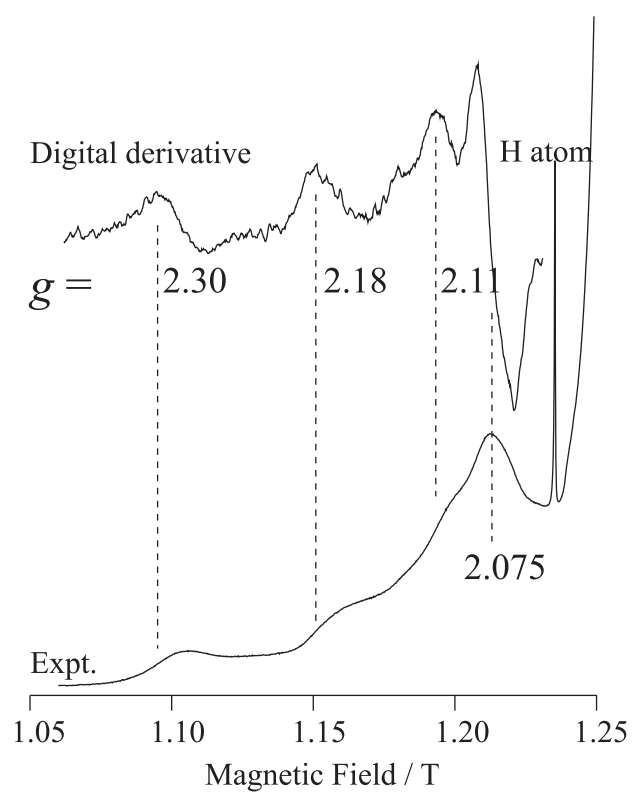

Figure 6. EPR spectrum of $t t t-\left[\mathrm{Ni}^{\mathrm{II}}(\mathrm{OEiBC})\right]$ in 2-Methf solution $\gamma$-irradiated at $77 \mathrm{~K}$. The spectrum was recorded at $2 \mathrm{~K}$ (and $35.227 \mathrm{GHz}$ ) under passage conditions; both the experimental absorption lineshape (lower trace) and a digital first derivative (upper trace) are shown with their simulations. The sharp peak at $1.235 \mathrm{~T}$ is due to a hyperfine split partner of the EPR spectrum of the $\mathrm{H}$ atom. The large radical signal at lower fields is truncated. There is one $g_{\perp}$ feature at 2.075 and several $g_{\|}$features as indicated.

observed here by EPR is not surprising. The sample was then briefly ( $c a .5 \mathrm{~s}$ ) warmed to $300 \mathrm{~K}$ under nitrogen atmosphere (long enough to ensure thawing of the solution) and then refrozen in liquid nitrogen. The resulting EPR spectrum is shown in Figure 7. A weak signal remains at $g_{\|}=2.30$; its associated $g_{\perp}$ partner is difficult to determine, but might be in the region $g_{\perp}=2.05(5)$ as there is no longer a clear feature at $g_{\perp}=2.075$. This minor species corresponds to the tetragonal system seen for chemically generated $\left[\mathrm{Ni}^{\mathrm{I}}(\mathrm{OEiBC})\right]^{-}$. In addition, however, there is a strong, slightly rhombic signal that is readily simulated with $\mathbf{g}=[2.195,2.105,2.095]$. This signal is similar to that seen for $\mathrm{Ni}^{\mathrm{I}}$ in $\mathrm{MCR}_{\mathrm{red} 2}$ ?,99 perhaps coincidentally, as there is no thiolate ligand available in the $\mathrm{Ni}(\mathrm{OEiBC})$ solution, and the 2-Methf solvent would be expected to coordinate relatively weakly; less so even than thf for steric reasons.

\section{9. $35 \mathrm{GHz}$ EPR Spectra of $\gamma$-irradiated [NiII $(\mathrm{OEP})$ ]}

The final system to be discussed is $\mathrm{Ni}(\mathrm{OEP})$. In this case, there has hitherto been no evidence for other than a ligand-centered reduction - no $\mathrm{Ni}^{\mathrm{I}}$ species has been observed, and the chemically generated ligand-centered radical is very unstable. ${ }^{49}$ With $\mathrm{Ni}(\mathrm{OEP})$, however, the efficacy and unique ability of the $\gamma$-irradiation (cryoreduction) method is demonstrated. The result of $\gamma$-irradiation at $77 \mathrm{~K}$ of $\mathrm{Ni}(\mathrm{OEP})$ in 2-Methf solution

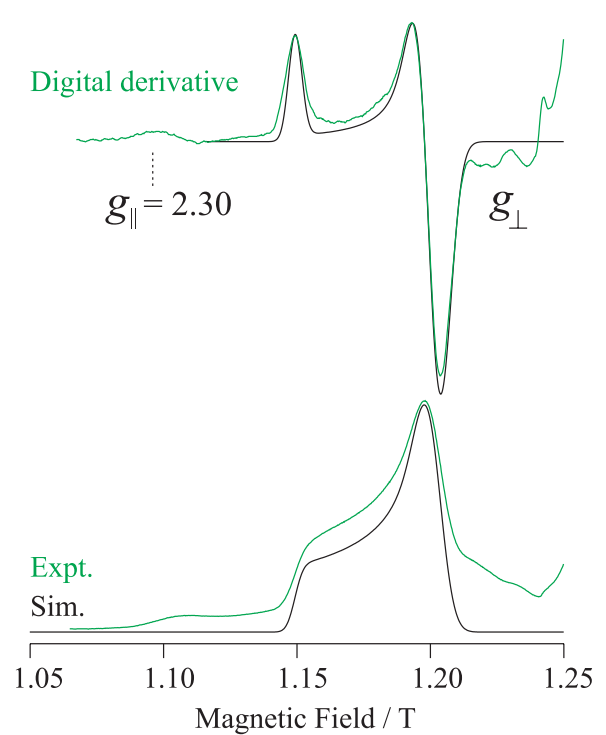

Figure 7. Experimental (dashed trace (colored in online version)) and simulated (solid black trace) EPR spectrum of $t t t-\left[\mathrm{Ni}^{\mathrm{II}}(\mathrm{OEiBC})\right]$ in 2-Methf solution $\gamma$-irradiated at $77 \mathrm{~K}$ and then warmed to $300 \mathrm{~K}$ for $5 \mathrm{~s}$ under $\mathrm{N}_{2}$ atmosphere. The spectrum was recorded at $2 \mathrm{~K}$ (and $35.314 \mathrm{GHz}$ ) under passage conditions; both the experimental absorption lineshape (lower dashed (colored) trace) and a digital first derivative (upper dashed (colored) trace) are shown with their simulations. The large radical signal at lower fields is truncated. The simulation parameters are $\mathbf{g}=[2.195,2.105,2.095]$, $W=[90,140,140] \mathrm{MHz}$ (single crystal Gaussian linewidths, hwhm). There is an additional feature at $g_{\|}=2.30$ as indicated; its $g_{\perp}$ partner may be in the field region indicated.

is shown in Figure 8. In contrast to the results for $\mathrm{Ni}(\mathrm{OEiBC})$, a nearly homogeneous EPR signal results, which can be simulated by $\mathbf{g}=[2.179,2.093,2.090]$.

The slightly rhombic signal seen for $\left[\mathrm{Ni}^{\mathrm{I}}(\mathrm{OEiBC})\right]^{-}$is unsurprising, given the asymmetry of the pyrrole/pyrroline groups, while the nearly axial tensor of $\left[\mathrm{Ni}^{\mathrm{I}}(\mathrm{OEP})\right]^{-}$is also expected given the $D_{4 h}$ symmetry of the parent $\mathrm{Ni}(\mathrm{OEP})$. Both species, however, exhibit $g_{\perp}$ values that are slightly larger and $g_{\|}$values very slightly smaller than is typical for tetragonal $\mathrm{d}^{9}$ systems, whether sq pl or sq pyr. This EPR signature may result from distortion from sq pl towards tetrahedral geometry. As evidence, we may consider another tetraaza macrocyclic ligand, $n, m$-tropocoronand (diagram below), developed by Lippard and co-workers. ${ }^{116,117}$

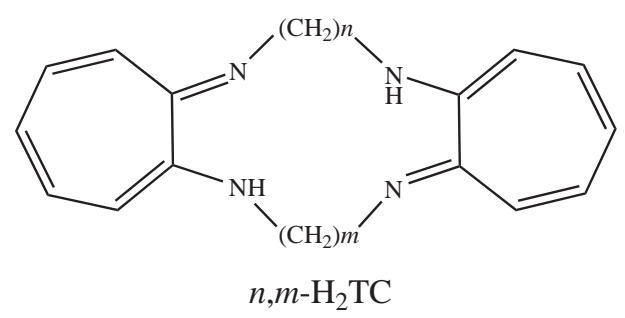

The dianion of this ligand forms distorted 4-coordinate $\mathrm{Cu}^{\mathrm{II} 116}$ and $\mathrm{Ni}^{\mathrm{II}}$ complexes ${ }^{117}$ that approach pseudotetrahedral geometry. In the $\mathrm{Cu}^{\mathrm{II}}$ complexes, this is manifest in EPR 


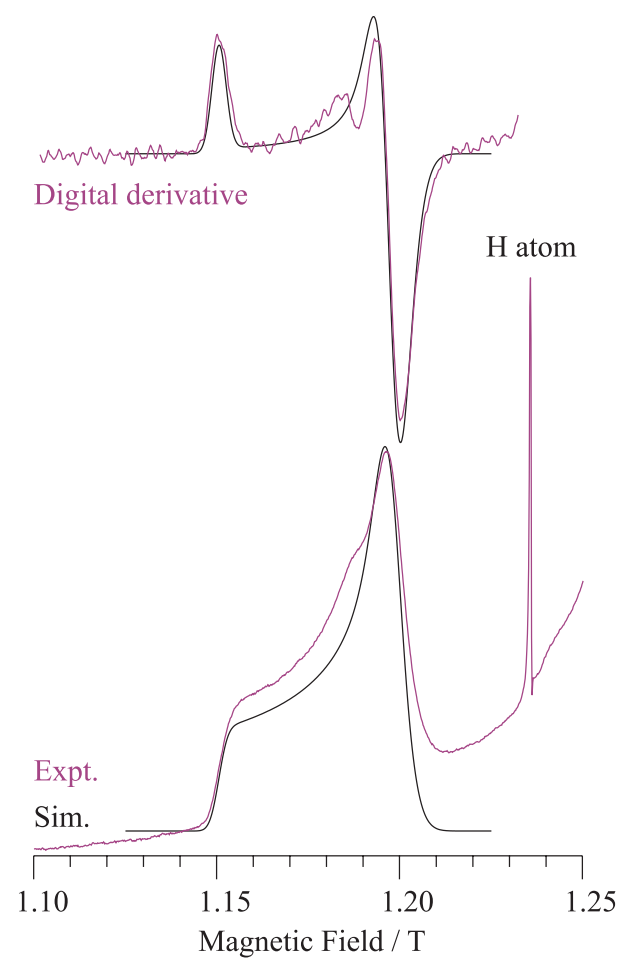

Figure 8. Experimental (dashed trace (colored in online version)) and simulated (solid black trace) EPR spectrum of $\left[\mathrm{Ni}^{\mathrm{II}}(\mathrm{OEP})\right]$ in 2-Methf solution $\gamma$-irradiated at $77 \mathrm{~K}$. The spectrum was recorded at $2 \mathrm{~K}$ (and $35.092 \mathrm{GHz}$ ) under passage conditions; both the experimental absorption lineshape (lower dashed (colored) trace) and a digital first derivative (upper dashed (colored) trace) are shown with their simulations. The sharp peak at $1.235 \mathrm{~T}$ is due to a hyperfine split partner of the EPR spectrum of the $\mathrm{H}$ atom. The simulation parameters are $\mathbf{g}=[2.179,2.093,2.090], W=[70$, $90,150] \mathrm{MHz}$ (single crystal Gaussian linewidths, hwhm). There is an additional feature at $c a .1 .19 \mathrm{~T}\left(g_{\perp} c a .2 .11\right)$, but no attempt was made to simulate this minor component.

parameters similar to those seen above for cryoreduced $\mathrm{Ni}^{1}$ tetrapyrroles: $g_{\|} \cong 2.15, g_{\perp} \cong 2.08,{ }^{116}$ i.e., $g_{\|}$lower and $g_{\perp}$ higher than "normal". The overall situation for both $\left[\mathrm{Ni}^{\mathrm{I}}(\mathrm{OEiBC})\right]^{-}$and $\left[\mathrm{Ni}^{\mathrm{I}}(\mathrm{OEP})\right]^{-}$is thus reasonable for a tetragonal $\mathrm{Ni}^{1}$ system, but with perhaps some ruffling/ saddling that distorts the geometry and mixes in a small amount of $3 d_{z^{2}}$ (and even $4 p_{z}$ ) character into the ground state, increasing $g_{\perp}$. The EPR spectra seen here for $\left[\mathrm{Ni}^{\mathrm{I}}(\mathrm{OEiBC})\right]^{-}$and $\left[\mathrm{Ni}^{\mathrm{I}}(\mathrm{OEP})\right]^{-}$generated by cryoreduction are also similar to the rhombic signal seen for radiolytically generated $\left[\mathrm{Ni}\left(\mathrm{Me}_{6} \mathrm{tmc}\right)\right]^{+} .{ }^{79}$

$\left[\mathrm{Ni}^{\mathrm{I}}(\mathrm{OEP})\right]^{-}$, however, is quite different from $\left[\mathrm{Ni}^{\mathrm{I}}(\mathrm{OEiBC})\right]^{-}$in terms of thermal stability, in agreement with Stolzenberg's studies in fluid solution. Brief thawing under nitrogen as described above leads to disappearance of this signal (the radical signal remains, although such signals can result from a variety of radiation processes, not only $\left.\left[\mathrm{Ni}^{\mathrm{II}}(\mathrm{OEP})^{\bullet}\right]^{-}\right)$. The reason for the instability of $\left[\mathrm{Ni}^{\mathrm{I}}(\mathrm{OEP})\right]^{-}$ cannot be discerned by EPR, as the spectra are so similar to those for $\left[\mathrm{Ni}^{\mathrm{I}}(\mathrm{OEiBC})\right]^{-}$generated in the same way. EPR does not interrogate the relative stability of the ligandcentered radical or other decay products. Nevertheless, it is significant that $\left[\mathrm{Ni}^{\mathrm{I}}(\mathrm{OEP})\right]^{-}$can be generated and we hope that these results will contribute to further computational studies, such as have been successfully performed on these and related porphyrinic complexes. .5 $56,68,69,118,119$

\section{Conclusions}

The reduction of tetraaza macrocyclic complexes of nickel might seem to be an overly narrowly defined area on which to focus. Yet these complexes have a great biological relevance in terms of their role in MCR, with its cofactor $\mathrm{F}_{430}$. This biological relevance raises two interesting questions, which have yet to be fully answered. The first question concerns the competition between ligand-centered and metal-centered reduction. Fully saturated macrocycles give $\mathrm{Ni}^{\mathrm{I}}$ upon reduction, as do those with unconjugated imino groups; however, the slightest conjugation ( $\alpha$-diimine) leads to formation of a ligandbased radical anion. This would seem to be the end of the story, but much more highly unsaturated macrocycles, such as $\mathrm{OEiBC}$ and $\mathrm{F}_{430}$, yield stable $\mathrm{Ni}^{\mathrm{I}}$ species upon chemical or electrochemical reduction in aqueous and organic solvents. We show here that even the most unsaturated macrocycle, namely a porphyrin, $\mathrm{Ni}(\mathrm{OEP})$, can yield a $\mathrm{Ni}^{\mathrm{I}}$ product when the reduction is done in such a way as to prevent rearrangement processes. The second question concerns the nature of the $\mathrm{Ni}^{\mathrm{I}}$ species - typically tetragonal (sq pyr) as in $\mathrm{Cu}^{\mathrm{II}}$ tetrapyrroles, ${ }^{18}$ or, more surprisingly, tbp, as in $\mathrm{Cu}^{\mathrm{II}}$ with specifically designed quinquidentate ligands. ${ }^{105,106}$

Tetraaza macrocyclic complexes of $\mathrm{Ni}^{\mathrm{I}}$, in the presence of weakly (nitriles) or strongly (CO) coordinating ligands can exhibit EPR spectra that are diagnostic of substantial conversion from sq $\mathrm{pl} / \mathrm{sq}$ pyr to nearly tetrahedral/tbp geometry. The sensitivity of EPR to this transformation is the consequence of mixing between $d_{x^{2}-y^{2}}$ and $d_{z^{2}}{ }^{1}$ electronic ground states. This phenomenon is found for the more flexible, unsaturated ligands (tmc and $\mathrm{Me}_{6}[14] 4,11$ diene $\mathrm{N}_{4}$ ); however, even the unsaturated $\mathrm{OEiBC}$ and OEP complexes of $\mathrm{Ni}^{\mathrm{I}}$ (when generated by cryoreduction) can exhibit EPR spectra that are not purely tetragonal. It is hoped that new complexes will be synthesized that can support $\mathrm{Ni}^{\mathrm{I}}$, such as has been done by Riordan and coworkers. ${ }^{107}$ Previously reported complexes could also be reinvestigated in the context of MCR model chemistry, such as $\mathrm{Ni}(\mathrm{TMiBC})$ and the $n, m$-tropocoronand complexes of $\mathrm{Ni}^{\mathrm{I}} .{ }^{117}$ It would be of interest to see if these complexes could be reducible to $\mathrm{Ni}^{\mathrm{I}}$ - one would think that a ligandcentered reduction could occur, but that would have been expected for OEiBC as well. 


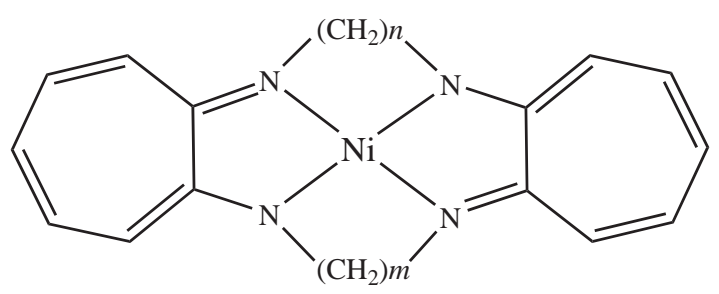

There is thus still room for much additional work, both experimental and theoretical, to understand tetraaza macrocyclic complexes of nickel in both bioinorganic and classical coordination chemistry.

\section{Acknowledgments}

I would like to thank my many extremely talented collaborators who have generously provided a number of synthetically challenging macrocyclic complexes of Ni: Prof. Charles G. Riordan, University of Delaware, Newark, DE, USA for Ni(tmc), who also provided helpful comments; Drs. Etsuko Fujita and Mark W. Renner, Brookhaven National Laboratory, Upton, NY, USA for $\mathrm{Ni}_{\left(\mathrm{Me}_{6}[14] 4,11-\text { dieneN }_{4}\right)}$ and $\mathrm{Ni}(\mathrm{OEiBC})$ complexes, respectively; Prof. Robert A. Scott, University of Georgia, Athens, GA, USA and Prof. Stephen W. Ragsdale, University of Michigan, Ann Arbor, MI, USA for $\mathrm{F}_{430}$ and MCR samples, respectively. I also thank Dr. Roman Davydov, Northwestern University, Evanston, IL, USA for performing the $\gamma$-irradiation of samples, which was done in the Department of Radiation Oncology, Pritzker School of Medicine, The University of Chicago. I especially wish to thank Prof. Brian M. Hoffman, Northwestern University, for use of his X-band and $35 \mathrm{GHz}$ EPR spectrometers, which facilities are supported by the NSF and NIH. I also wish to acknowledge Roosevelt University for financial support of this research over the years. Lastly, this paper is dedicated to the fond memory of Prof. Ícaro de Sousa Moreira, Universidade Federal do Ceará, Fortaleza, CE, Brazil.



Joshua Telser was born in Chicago, IL, USA. He received his $A B$ from Cornell University (Ithaca, $N Y)$ and his $P h D$ from the University of Florida under the direction of the late Prof. Russell S. Drago. He was an NIH postdoctoral fellow with Prof. Brian M. Hoffman at Northwestern University (Evanston,

IL). After a period in industry, he joined the faculty of Roosevelt University (Chicago and Schaumburg, IL) where he is currently an Associate Professor of Chemistry and Assistant Chair of the Department of Biological, Chemical and Physical Sciences. He is a member of the ACS, the International EPR(ESR) Society, the Society of Biological Inorganic Chemistry (SBIC), and the International Porphyrin and Phthalocyanine Society. His research interests include the biological and inorganic chemistry of paramagnetic transition metal ions and the application of paramagnetic resonance spectroscopy and magnetic measurements to these systems.

\section{References}

1. Abragam, A.; Bleaney, B.; Electron Paramagnetic Resonance of Transition Ions, Dover Publications, Inc.: New York, 1986.

2. McGarvey, B. R.; Trans. Metal Chem., Ser. Advan. 1966, 3, 89.

3. Peisach, J.; Blumberg, W. E.; Arch. Biochem. Biophys. 1974, $165,691$.

4. Hyde, J. S.; Froncisz, W.; Ann. Rev. Biophys. Bioeng. 1982, 11, 391.

5. Weil, J. A.; Bolton, J. R.; Wertz, J. E.; Electron Paramagnetic Resonance: Elementary Theory and Practical Applications, John Wiley \& Sons, Inc: New York, 1994.

6. Pilbrow, J. R.; Transition Ion Electron Paramagnetic Resonance, Clarendon Press: Oxford, 1990.

7. Cotton, F. A.; Wilkinson, G.; Murillo, C. A.; Bochmann, M.; Advanced Inorganic Chemistry, $6^{\text {th }}$ ed.; Wiley: New York, 1999 , pp. 864-876.

8. Karlin, K. D.; Tyeklár, Z.; Bioinorganic Chemistry of Copper, Chapman \& Hall: New York, 1993.

9. Rosenzweig, A. C.; Acc. Chem. Res. 2001, 34, 119.

10. Gaggelli, E.; Kozlowski, H.; Valensin, D.; Valensin, G.; Chem. Rev. 2006, 106, 1995.

11. Vieira, E. D.; Casado, N. M. C.; Facchin, G.; Torre, M. H.; Costa-Filho, A. J.; Calvo, R.; Inorg. Chem. 2006, 45, 2942.

12. Ozarowski, A.; Szymanska, I. B.; Muzioł, T.; Jezierska, J.; J. Am. Chem. Soc. 2009, 131, 10279.

13. Maki, A. H.; McGarvey, B. R.; J. Chem. Phys. 1958, 29, 31.

14. Maki, A. H.; McGarvey, B. R.; J. Chem. Phys. 1958, 29, 35.

15. Boča, R.; Coord. Chem. Rev. 2004, 248, 757.

16. Desrochers, P. J.; Telser, J.; Zvyagin, S. A.; Ozarowski, A.; Krzystek, J.; Vicic, D. A.; Inorg. Chem. 2006, 45, 8930.

17. Dobrzyńska, D.; Jerzykiewicz, L. B.; Duczmal, M.; Wojciechowska, A.; Jabłońska, K.; Palus, J.; Ożarowski, A. Inorg. Chem. 2006, 45, 10479.

18. Brown, T. G.; Hoffman, B. M.; Mol. Phys. 1980, 39, 1073.

19. Elschenbroich, C.; Organometallics, $3^{\text {rd }}$ ed., Wiley-VCH: Weinheim, Germany, 2006.

20. Lovecchio, F. V.; Gore, E. S.; Busch, D. H.; J. Am. Chem. Soc. 1974, 96, 3109.

21. Schönheit, P.; Moll, J.; Thauer, R. K.; Arch. Microbiol. 1980, $127,59$.

22. Thauer, R. K.; Microbiology 1998, 144, 2377. 
23. Telser, J. In Structure and Bonding; Williams, R. J. P., ed.; Springer Verlag: Heidelberg, 1998, Vol. 91, pp. 31-63.

24. Harmer, J.; Finazzo, C.; Piskorski, R.; Bauer, C.; Jaun, B.; Duin, E. C.; Goenrich, M.; Thauer, R. K.; Doorslaer, S. V.; Schweiger, A.; J. Am. Chem. Soc. 2005, 127, 17744.

25. Harmer, J.; Finazzo, C.; Piskorski, R.; Ebner, S.; Duin, E. C.; Goenrich, M.; Thauer, R. K.; Reiher, M.; Schweiger, A.; Hinderberger, D.; Jaun, B.; J. Am. Chem. Soc. 2008, 130, 10907.

26. Sarangi, R.; Dey, M.; Ragsdale, S. W.; Biochemistry 2009, 48 , 3146.

27. Pfaltz, A.; Juan, B.; Fassler, A.; Eschenmoser, A.; Jaenchen, R.; Gilles, H. H.; Diekart, G.; Thauer, R. K.; Helv. Chim. Acta 1982, 65, 828.

28. Pfaltz, A.; Livingston, D. A.; Jaun, B.; Diekert, G.; Thauer, R. K.; Eschenmoser, A.; Helv. Chim. Acta 1985, 68, 1338.

29. Shiemke, A. K.; Kaplan, W. A.; Hamilton, C. L.; Shelnutt, J. A.; Scott, R. A.; J. Biol. Chem. 1989, 264, 7276.

30. Cheesman, M. R.; Ankel-Fuchs, D.; Thauer, R. K.; Thomson, A. J.; Biochem. J. 1989, 260, 613.

31. Hamilton, C. L.; Scott, R. A.; Johnson, M. K.; J. Biol. Chem. 1989, 264, 11605.

32. Albracht, S. P. J.; Ankel-Fuchs, D.; van der Zwaan, J. W.; Fontijn, R. D.; Thauer, R. K.; Biochim. Biophys. Acta 1986, $870,50$.

33. Jaun, B.; Pfaltz, A.; J. Chem. Soc., Chem. Comm. 1986, 1327.

34. Ellermann, J.; Hedderich, R.; Böcher, R.; Thauer, R. K.; Eur. J. Biochem. 1987, 172, 669.

35. Albracht, S. P. J.; Ankel-Fuchs, D.; Böcher, R.; Ellermann, J.; Moll, J.; van der Zwaan, J. W.; Thauer, R. K.; Biochim. Biophys. Acta 1988, 955, 86.

36. Finazzo, C.; Harmer, J.; Jaun, B.; Duin, E. C.; Mahlert, F.; Thauer, R. K.; Doorslaer, S. V.; Schweiger, A.; J. Biol. Inorg. Chem. 2003, 8, 586.

37. Ermler, U.; Grabarse, W.; Shima, S.; Goubeaud, M.; Thauer, R. K.; Science 1997, 278, 1457.

38. Grabarse, W.; Mahlert, F.; Duin, E. C.; Goubeaud, M.; Shima, S.; Thauer, R. K.; Lamzin, V.; Ermler, U.; J. Mol. Biol. 2001, $309,315$.

39. Färber, G.; Keller, W.; Kratky, C.; Jaun, B.; Pfaltz, A.; Spinner, C.; Kobelt, A.; Eschenmoser, A.; Helv. Chim. Acta 1991, 74, 697.

40. Furenlid, L. R.; Renner, M. W.; Fajer, J.; J. Am. Chem. Soc. 1990, 112, 8987.

41. Furenlid, L. R.; Renner, M. W.; Smith, K. M.; Fajer, J.; J. Am. Chem. Soc. 1990, 112, 1634

42. Lahiri, G. K.; Stolzenberg, A. M.; Inorg. Chem. 1993, 32, 4409.

43. Procyk, A. D.; Stolzenberg, A. M.; Bocian, D. F.; Inorg. Chem. 1993, 32, 627 .

44. Renner, M. W.; Furenlid, L. R.; Barkigia, K. M.; Forman, A.; Shim, H. K.; Simpson, D. J.; Smith, K. M.; Fajer, J.; J. Am. Chem. Soc. 1991, 113, 6891.
45. Renner, M. W.; Furenlid, L. R.; Stolzenberg, A. M.; J. Am. Chem. Soc. 1995, 117, 293.

46. Stolzenberg, A. M.; Spreer, L. O.; Holm, R. H.; J. Am. Chem. Soc. 1980, 102, 364.

47. Stolzenberg, A. M.; Stershic, M. T.; Inorg. Chem. 1987, 26, 3082.

48. Stolzenberg, A. M.; Stershic, M. T.; J. Am. Chem. Soc. 1988, 110, 5397.

49. Stolzenberg, A. M.; Stershic, M. T.; J. Am. Chem. Soc. 1988, $110,6391$.

50. Telser, J.; Fann, Y.; Renner, M. W.; Fajer, J.; Wang, S.; Zhang, H.; Scott, R. A.; Hoffman, B. M.; J. Am. Chem. Soc. 1997, 119, 733.

51. Campbell, C. J.; Rusling, J. F.; Brückner, C.; J. Am. Chem. Soc. 2000, 122, 6679 .

52. Waditschatka, R.; Kratky, C.; Jaun, B.; Heinzer, J.; Eschenmoser, A.; J. Chem. Soc., Chem. Commun. 1985, 1604.

53. Lahiri, G. K.; Schussel, L. J.; Stolzenberg, A. M.; Inorg. Chem. 1992, 31, 4991.

54. Zimmer, M.; Crabtree, R. H.; J. Am. Chem. Soc. 1990, 112, 1062.

55. Ghosh, A.; Acc. Chem. Res. 1998, 31, 189-198.

56. Wondimagegn, T.; Ghosh, A.; J. Phys. Chem. B 2000, 104, 10858-10862.

57. Gagné, R. R.; Ingle, D. M.; Inorg. Chem. 1981, 20, 420-425.

58. Furenlid, L. R.; Renner, M. W.; Szalda, D. J.; Fujita, E.; J. Am. Chem. Soc. 1991, 113, 883-892.

59. Johnson, L. K.; Killian, C. M.; Brookhart, M.; J. Am. Chem. Soc. 1995, 117, 6414.

60. Feldman, J.; McLain, S. J.; Parthasarathy, A.; Marshall, W. J.; Calabrese, J. C.; Arthur, S. D.; Organometallics 1997, 16, 1514.

61. Allan, L. E. N.; Shaver, M. P.; White, A. J. P.; Gibson, V. C.; Inorg. Chem. 2007, 46, 8963.

62. Bai, G.; Wei, P.; Das, A.; Stephan, D. W.; Organometallics 2006, 25,5870 .

63. Bai, G.; Wei, P.; Stephan, D. W.; Organometallics 2005, 24, 5901.

64. Craft, J. L.; Horng, Y.-C.; Ragsdale, S. W.; Brunold, T. C.; J. Am. Chem. Soc. 2004, 126, 4068.

65. Craft, J. L.; Horng, Y.-C.; Ragsdale, S. W.; Brunold, T. C.; J. Biol. Inorg. Chem. 2004, 9, 77.

66. Dey, M.; Kunz, R. C.; Heuvelen, K. M. V.; Craft, J. L.; Horng, Y.-C.; Tang, Q.; Bocian, D. F.; George, S. J.; Brunold, T. C.; Ragsdale, S. W.; Biochemistry 2006, 45, 11915.

67. Schenker, R.; Mock, M. T.; Kieber-Emmons, M. T.; Riordan, C. G.; Brunold, T. C.; Inorg. Chem. 2005, 44, 3605.

68. Wondimagegn, T.; Ghosh, A.; J. Am. Chem. Soc. 2000, 122, 6375.

69. Ryeng, H.; Gonzalez, E.; Ghosh, A.; J. Phys. Chem. B 2008, $112,15158$.

70. Chmielewski, P.; Grzeszczuk, M.; Latos-Grażyński, L.; Lisowski, J.; Inorg. Chem. 1989, 28, 3546. 
71. Brennan, T. D.; Scheidt, W. R.; Shelnutt, J. A.; J. Am. Chem. Soc. 1988, 110, 3919.

72. Stolzenberg, A. M.; Schussel, L. J.; Summers, J. S.; Foxman, B. M.; Petersen, J. L.; Inorg. Chem. 1992, 31, 1678.

73. Suh, M. P.; Swepston, P. N.; Ibers, J. A.; J. Am. Chem. Soc. 1984, 106, 5164.

74. Gallucci, J. C.; Swepston, P. N.; Ibers, J. A.; Acta Cryst. 1982, B38, 2134.

75. Szalda, D. J.; Fujita, E.; Acta Cryst. 1992, C48, 1767.

76. Ram, M. S.; Riordan, C. G.; Ostrander, R.; Rheingold, A. L.; Inorg. Chem. 1995, 34, 5884.

77. Barefield, E. K.; Freeman, G. M.; VanDerveer, D. G.; Inorg. Chem. 1986, 25, 552.

78. Bakac, A.; Espenson, J. H.; J. Am. Chem. Soc. 1986, 108, 713.

79. Jubran, N.; Ginzburg, G.; Cohen, H.; Koresh, Y.; Meyerstein, D.; Inorg. Chem. 1985, 24, 251.

80. Jubran, N.; Ginzburg, G.; Cohen, H.; Meyerstein, D.; J. Chem. Soc., Chem. Commun. 1982, 517.

81. Lee, T.-Y.; Hsieh, M.-Y.; Lee, T.-J.; Chen, J.-W.; Chung, C.-S.; Acta Cryst. 1986, C42, 1001.

82. Davydov, A.; Davydov, R.; Gräslund, A.; Lipscomb, J. D.; Andersson, K. K.; J. Biol. Chem. 1997, 272, 7022.

83. Telser, J.; Davydov, R.; Kim, C.-H.; Adams, M. W. W.; Inorg. Chem. 1999, 38, 3550.

84. Davydov, R.; Macdonald, I. D. G.; Makris, T. M.; Sligar, S. G.; Hoffman, B. M.; J. Am. Chem. Soc. 1999, 121, 10654.

85. Kim, S. H.; Yang, T.-C.; Perera, R.; Jin, S.; Bryson, T. A.; Sono, M.; Davydov, R.; Dawson, J. H.; Hoffman, B. M.; Dalton Trans. 2005, 21, 3464.

86. Telser, J.; Davydov, R.; Horng, Y.-C.; Ragsdale, S. W.; Hoffman, B. M.; J. Am. Chem. Soc. 2001, 123, 5853.

87. Becker, D. F.; Ragsdale, S. W.; Biochemistry 1998, 37, 2369.

88. Mailer, C.; Taylor, C. P. S.; Biochim. Biophys. Acta 1973, 322, 195.

89. Davydov, R.; Sahlin, M.; Kuprin, S.; Gräslund, A.; Ehrenberg, A.; Biochemistry 1996, 35, 5571.

90. Davydov, R.; Satterlee, J. D.; Fujii, H.; Sauer-Masarwa, A.; Busch, D. H.; Hoffman, B. M.; J. Am. Chem. Soc. 2003, 125, 16340.

91. Davydov, R. M.; Yoshida, T.; Ikeda-Saito, M.; Hoffman, B. M.; J. Am. Chem. Soc. 1999, 121, 10656.

92. Belford, R. L.; Belford, G. G.; J. Chem. Phys. 1973, 59, 853.

93. Belford, R. L.; Nilges, M. J.; EPR Symposium, 21st Rocky Mountain Conference, Denver, Colorado, 1979.

94. Holliger, C.; Pierik, A. J.; Reijerse, E. J.; Hagen, W. R.; J. Am. Chem. Soc. 1993, 115, 5651.

95. Kaplan, W. A.; Suslick, K. S.; Scott, R. A.; J. Am. Chem. Soc. 1991, 113, 9824.

96. Hitchman, M. A.; J. Chem. Soc. (A) 1970, 1970, 4.

97. Hitchman, M. A.; Olson, C. D.; Belford, R. L.; J. Chem. Phys. 1969, 50, 1195.
98. Telser, J.; J. Braz. Chem. Soc. 2006, 17, 1501.

99. Duin, E. C.; Signor, L.; Piskorski, R.; Mahlert, F.; Clay, M. D.; Goenrich, M.; Thauer, R. K.; Jaun, B.; Johnson, M. K.; J. Biol. Inorg. Chem. 2004, 9, 563.

100. Mahlert, F.; Bauer, C.; Jaun, B.; Thauer, R. K.; Duin, E. C.; J. Biol. Inorg. Chem. 2002, 7, 500.

101. Mahlert, F.; Grabarse, W.; Kahnt, J.; Thauer, R. K.; Duin, E. C.; J. Biol. Inorg. Chem. 2002, 7, 101.

102. Goubeaud, M.; Schreiner, G.; Thauer, R.; Eur. J. Biochem. 1997, $243,110$.

103. Even within $\mathrm{MCR}_{\text {red } 1}$ there are multiple forms, depending on the presence of other MCR forms, or substrate/products, etc. See Table 1 for examples.

104. Pak, R.; Scheidt, W. R.; Acta Cryst. 1991, C47, 431.

105. Barbucci, R.; Bencini, A.; Gatteschi, D.; Inorg. Chem. 1977, 16, 2117.

106. Bencini, A.; Bertini, I.; Gatteschi, D.; Scozzafava, A.; Inorg. Chem. 1978, 17, 3194

107. Kieber-Emmons, M. T.; Riordan, C. G.; Acc. Chem. Res. 2007, 40, 618.

108. Kieber-Emmons, M. T.; Annaraj, J.; Seo, M. S.; Heuvelen, K. M. V.; Tosha, T.; Kitagawa, T.; Brunold, T. C.; Nam, W.; Riordan, C. G.; J. Am. Chem. Soc. 2006, 128, 14230.

109. Gore, E. S.; Busch, D. H.; Inorg. Chem. 1973, 12, 1.

110. Martin, L. Y.; Sperati, C. R.; Busch, D. H.; J. Am. Chem. Soc. 1977, 99, 2968.

111. Lanci, M. P.; Smirnov, V. V.; Cramer, C. J.; Gauchenova, E. V.; Sundermeyer, J.; Roth, J. P.; J. Am. Chem. Soc. 2007, 129, 14697.

112. Chiesa, M.; Giamello, E.; Paganini, M. C.; Sojka, Z.; Murphy, D. M.; J. Chem. Phys. 2002, 116, 4266.

113. Fukuzumi, S.; Ohtsu, H.; Ohkubo, K.; Itoh, S.; Imahori, H.; Coord. Chem. Rev. 2002, 226, 71.

114. Barkigia, K. M.; Renner, M. W.; Furenlid, L. R.; Medforth, C. J.; Smith, K. M.; Fajer, J.; J. Am. Chem. Soc. 1993, 115, 3627.

115. Renner, M. W.; Barkigia, K. M.; Zhang, Y.; Medforth, C. J.; Smith, K. M.; Fajer, J.; J. Am. Chem. Soc. 1994, 116, 8582.

116. Davis, W. M.; Zask, A.; Nakanishi, K.; Lippard, S. J.; Inorg. Chem. 1985, 24, 3737.

117. Davis, W. M.; Roberts, M. M.; Zask, A.; Nakanishi, K.; Nozoe, T.; Lippard, S. J.; J. Am. Chem. Soc. 1985, 107, 3864.

118. Conradie, J.; Wondimagegn, T.; Ghosh, A.; J. Phys. Chem. B 2008, 112, 1053 .

119. Wondimagegn, T.; Ghosh, A.; J. Am. Chem. Soc. 2001, 123, 1543.

Received: September 25, 2009 Web Release Date: March 4, 2010 